\title{
INVESTIGATING THE EFFECT OF COMPRESSION ON SOLUTE TRANSPORT THROUGH DEGRADING MUNICIPAL SOLID WASTE*
}

\author{
N. D. WOODMAN, T. C. REES-WHITE, A. M. STRINGFELLOW, R. P.
} BEAVEN \& A. P. HUDSON

Faculty of Engineering and the Environment, University of Southampton, Highfield, Southampton, SO17 1BJ, UK

\begin{abstract}
The effect of applied compression on the nature of liquid flow and hence the movement of contaminants within Municipal Solid Waste was examined by means of thirteen tracer tests conducted on five separate waste samples. The conservative nature of bromide, lithium and deuterium tracers was evaluated and linked to the presence of degradation in the sample. Lithium and deuterium tracers were non-conservative in the presence of degradation, whereas the bromide remained effectively conservative under all conditions. Solute diffusion times into and out of less mobile blocks of waste were compared for each test under the assumption of dominantly dual-porosity flow. Despite the fact that hydraulic conductivity changed strongly with applied stress, the block diffusion times were found to be much less sensitive to compression. A simple conceptual model, whereby flow is dominated by sub-parallel low permeability obstructions which define predominantly horizontally aligned less mobile zones, is able to explain this result. Compression tends to narrow the gap between the obstructions, but not significantly alter the horizontal length scale. Irrespective of knowledge of the true flow pattern, these results show that simple models of solute flushing from landfill which do not include depth dependent changes in solute transport parameters are justified.
\end{abstract}

\section{INTRODUCTION}

The movement of potential contaminants arising from within Municipal Solid Waste (MSW) landfills is of relevance to managers, regulators and broader society. The contaminants (in the form of solutes and particles) are transported by the advective flow of water and by diffusion. Contaminants are flushed out by rainwater entering the landfill, or due to the introduction of additional fluids to the waste. There are a number of reasons why understanding flushing is important. Firstly, the contaminant loading (quality) and volume of

\footnotetext{
* NOTICE: this is the author's version of a work that was accepted for publication in Waste Management. Changes resulting from the publishing process, such as peer review, editing, corrections, structural formatting, and other quality control mechanisms may not be reflected in this document. Changes may have been made to this work since it was submitted for publication. A definitive version was subsequently published in Waste Management (2014), Vol 34 (11) pp 2196-2208 DOI: 10.1016/j.wasman.2014.06.022
} 
the leachate arising from the site over time affects the engineering of leachate storage and treatment facilities. Secondly, depending on circumstances, the generated flux and concentration of mobile contaminants in the leachate and the remaining mobilisable mass within the waste are important in determining potential pollution risks posed by the waste. The evaluation of the present and projected nature of this 'source term' (together with sitespecific factors, including the engineered barriers and nature of the surrounding environment) will be important in ensuring that adequate levels of environmental protection are maintained. Since timescales of the order of many decades or even centuries may be appropriate (Harris et al., 1994), uncertainties surrounding flushing processes are likely to relate to significant uncertainties in future financial and societal costs. Understanding waste flushing requires knowledge of the nature of the key transport processes through wastes and how these change under different conditions. The effect on flow and solute movement due to the generation of gas and settlement in degrading organic waste over time has been examined by Woodman et al. (2013b). Aside this relatively uncontrolled natural process, certain site conditions can be controlled by engineers. For example, waste can be pre-treated by shredding and screening to give a maximum particle size.

There is an existing body of literature on how the hydraulic behaviour of municipal solid waste is affected by compression (e.g. Powrie and Beaven, 1999; Hudson et al., 1999, 2001, 2004; Stoltz et al., 2010; Olivier \& Gourc, 2007). As well as variation due to different methods of compaction, waste in a landfill can be substantially compressed by the weight of overlying layers, which may reach several tens of metres deep. Compression flattens deformable objects and closes up pore-space. The result is a higher bulk density, reduced water-filled and drainable porosities, and lower permeability (Powrie \& Beaven, 1999; Beaven, 2000). Hydraulic conductivity has been shown to vary over five orders of magnitude when total applied stress is varied from 50 to $600 \mathrm{kPa}$ (e.g. Powrie \& Beaven, 1999). These changes have potentially profound implications for water flow through landfill and, therefore, upon site operation and management. Therefore, compression has a significant impact on advection rates, volumes of liquid and gas which can be stored within the waste and the volume which will be retained at 'field capacity'.

The rate of advection exerts a strong control over solute movement; slower flow implies slower movement of solute in the portion of the waste with flowing leachate. The pattern of the flow may also change with compression. Given the heterogeneous nature of MSW, there is evidence (e.g. Bengtsson et al., 1994; Ehrig, 1983) that rather than being uniformly distributed, flow is concentrated into preferential pathways with less mobile zones existing between these pathways. The nature and inter-connectivity of preferential flow paths may change under compression with a tendency for pathways to either converge or disperse. By implication, less mobile zones of the waste would change shape and/or size in response to any changes in preferred pathways. Since the removal of contaminant from less mobile zones is likely to be dominated by diffusive fluxes, changes to the timescale of mass transfer from these regions is potentially important. The effect of compression on this slower diffusively rate-limited release has not been systematically reported in the literature. Given that compression affects bulk flow rates and porosity, large changes might be anticipated on the pattern of the flow and hence solute movement. This is important, as the time taken for sufficient contaminant dilution to occur is a key factor in determining the period of time after which an operator may handover responsibility for the 'completed' site (other factors are also important, including degradation, waste and leachate composition and temperature). The duration of the dilution period is dependent both on the time of advection through the more mobile portions of the pore space and on the time of diffusion through the less mobile 
portions. This paper aims to quantify the effect of compression on this latter, less welldescribed aspect of solute transport, based on evidence gained from a programme of tracer experiments. More specific research questions are, (i) does compression change the inferred block diffusion time and (ii) do other key variables affect this relationship (i.e. scale of measurement, waste type)?

\section{MATERIALS AND METHODS}

This study draws from and adds to the results from a series of previously reported closedloop tracer tests on wastes compressed at different applied loads (see Table 1). In Test 0 and Tests 8-13 the simulated results have been reported separately (Woodman et al. 2013a, $2013 \mathrm{~b}$ ) and are combined with new simulations for Tests 1-7 to provide a more comprehensive analysis of the effect of compression than would be achieved for a single sample. The effect of compression of each sample is examined and compared to the other samples (thus scoping for whether waste type and sample size are important compared to the primary compression variable)

Table 1. Summary of tracer tests

\subsection{EXPERIMENTAL SETUP}

The experiments shared a basic configuration. Each cell had a mixed reservoir of leachate which flowed through the waste and was pumped back to the reservoir after exiting via the cell outlet. The closed-loop configuration is an alternative to conventional 'in-line' tracer test (where the fluid leaving the column is not fed back to the inlet). The closed-loop column can be kept in a (dynamic) physical and chemical equilibrium, with the exception of the changing tracer concentration (Woodman et al., 2009). This is more difficult to achieve in an 'in-line' test, where fresh water and tracer are injected at the inlet, potentially altering the conditions of the waste-leachate system (for example affecting $\mathrm{pH}$ over time).

The reservoir in tests 3-7 were mixed manually using a stirrer following tracer addition and thereafter by means of a pump recirculating liquid from the bottom to the top of the tank. Tests 1-2 and 8-13 relied for mixing on the turbulence generated by the cascading inflow of recirculated liquid to the top of the reservoir. The exception of all the tests was Test 0 in which the outlet fluid was run to drain, in the manner of an ordinary column tracer experiment.

In all tests the waste was enclosed top and bottom by layers of gravel to provide welldistributed flow into and out of the waste. Figure 1 provides schematics of the apparatus. Each cell was in hydraulic equilibrium before the tracer tests commenced. The tracer tests were started by instantaneously adding and mixing a tracer into the leachate reservoir and thereafter sampled in the reservoir (sample point ' $R$ ') and/or at the outlet to the waste cell (sample point 'O'). The samples provided a number of breakthrough curves (BTCs), which were analysed firstly in terms of mass-balance and secondly by modelling. The tests were all run for approximately a month (in the range 26 to 45 days). 
Figure 1. Schematic of major hydraulic elements in the closed-loop tracer tests.

Configuration (a) upflow with separate reservoir (tests 3-7), and (b) down-flow with reservoir above the waste (tests $1-2 \& 8-13$ )

\subsection{TRACERS}

Three different tracers were applied in these tests: deuterium (added as deuterium oxide, $\mathrm{D}_{2} \mathrm{O}$ ), lithium ( $\mathrm{Li}$ ) and bromide $(\mathrm{Br})$. $\mathrm{LiBr}$ was added in all the tests except for test 0 where $\mathrm{LiCl}$ was added as a tracer at the same as indigenous bromide was flushed out. The tracers, their measurement techniques and errors are detailed in Table 2.

Table 2. Tracer details for each test

Lithium has been used several times as a tracer for transport within MSW (Blakey et al., 1998; Öman and Rosqvist, 1999; Rosqvist \& Bendz, 1999; Beaven et al., 2003). Its common use in MSW is explained by its relatively low cost and frequently low background concentration (Harris, 1979; Blakey et al., 1998). Lithium has been shown to have a low affinity for sorption to waste under laboratory conditions (Stegemann et al., 2006). Leaching tests from a range of MSW-derived wastes indicate that leached concentrations of lithium show a dependency on $\mathrm{pH}$, possibly indicating the influence of mineral phases on solubility, but maximum leached concentrations in the $\mathrm{pH}$ range of $6-8$ were $<0.5 \mathrm{mg} / \mathrm{L}$ (Hans van der Sloot, personal communication).

There is relatively little known about the performance of deuterium as an artificial tracer in wastes, although it has been used as a natural tracer (Maloszewski et al.,1995). Significant isotopic enrichment has been observed in leachates in comparison to groundwater (Baedecker \& Back, 1979; Hackley et al., 1997; Raco et al., 2013), attributed to both evaporation and methanogenesis.

Bromide is assumed to be conservative in some media (Flury and Flühler, 1995). Ward et al. (1998) found that, out of the available 'solute-type' tracers for aquifers and soils, the halogens are most suitable, of which bromide is often preferred (as it often has lower and more stable background levels). Stegemann et al. (2006) showed minor linear bromide sorption to waste. Their maximum reported distribution coefficient $\left(K_{d}=26 \mathrm{~L} / \mathrm{kg}\right)$ predicts the concentration of the injected bromide to be reduced by $4 \%$ by partitioning to the solid phase and a retardation factor of 1.05 (assuming $\theta=0.4$ and $\rho_{B}=0.7 \mathrm{~kg} / \mathrm{L}$ ). The behaviour of bromide cannot therefore be automatically assumed to be perfectly conservative in all wasteleachate systems.

Ultimately, deductions as to the reactive nature of tracers are best made based though analysis of BTCs, since there are significant difficulties in relating batch sorption tests to column or field behaviour (Woodman et al., 2011). However, there is relatively little analysis of the performance of tracers in landfill leachates based on their BTCs in the literature. Woodman et al. (2009) examined the flushing of a broad suite of 38 inorganic species from waste, analysed by ICPMS. The flushing of all these species (except Li, which was an introduced tracer) was compared by normalising each to their starting concentration and plotting on the same axes. This gave a variety of behaviours, of which most importantly, a lower-bound to these measured normalised concentrations was shared by $\mathrm{Br}, \mathrm{Ni}, \mathrm{Rb}$ and Mg. Bulk electroconductivity (EC) also followed this line. All other species gave normalised flushing curves above this line which suggests that they were subject to other processes including desorption and production (for example, by dissolution from the waste). 
These results therefore suggest that $\mathrm{Br}$ was flushed effectively conservatively, together with the other species which described the lower bound. This bromide flushing curve is denoted Test 0 here.

These three potentially highly-suited waste tracers are directly compared in this paper.

\subsection{HYDRAULIC PROPERTY DETERMINATIONS}

The saturated and gas-accumulated volumetric water contents $(\theta)$ were obtained from waterbalances undertaken on all tests. Water balances on laboratory sized experiments (i.e. tests 1,2 and 8-13 - see below) were made by measuring water volumes input and output from the cells. The water balance on tests undertaken at a larger scale (tests 0 , and 3-6) were calculated using load cells to measure changes in total mass at the start of waste saturation (gas purged conditions), during reciculation (gas build up) and at the start of and throughout the experiemnt (gas accumulaed conditions). Following the last test (Test 6) in the sequence of compressions, the experimental cell was drained under gravity, and waste samples collected and oven-dried at $74^{\circ} \mathrm{C}$ were used to determine the total water content of the drained waste.

Hydraulic conductivity was measured for known steady-state flow and known head at either end of the cell (Powrie \& Beaven, 1999).

Drainable porosity is measured as the volumetric fraction of free-draining water which arises from an initially saturated column of waste (procedure given in Beaven, 2000).

\subsection{EXPERIMENTS}

Specifically tracer tests are compared under the following conditions (summarised in Table $1)$ :

Test 0: An in-line tracer and flushing test (i.e. not in closed-loop), which distinguishes this test from all the remaining reported closed-loop tests. This was performed in a degrading waste (MSW2) at $87 \mathrm{kPa}$ of applied stress in a $2 \mathrm{~m}$ diameter large-scale compression cell. Indigenous bromide was flushed out by water, and simultaneously a $\mathrm{LiCl}$ tracer was also injected. This test allows the traditional in-line test to be compared with flushing data and with closed loop (test 3).

Tests 1 \& 2: Two tests carried out in parallel on degraded Municipal Solid Waste (MSW1) in identical $0.48 \mathrm{~m}$ diameter laboratory cells under $50 \mathrm{kPa}$ and $150 \mathrm{kPa}$ applied stress. This test examined whether waste type affects how compression influences waste transport.

Tests 3-6: Degrading waste (MSW2) under four sequential compressions (87, 150, 300 and $600 \mathrm{kPa}$ applied uniaxial stress) on a single waste sample in the same $2 \mathrm{~m}$ diameter large-scale compression cell, immediately following Test 0 in the same waste. This test provided a large range in compression at a relatively large-scale.

Test 7: This was performed in a sub-sample of waste which was collected at the end of Test 6. The $600 \mathrm{kPa}$ applied load was removed (by retracting a top platen) and the sample collected by driving a $0.3 \mathrm{~m}$ diameter steel cylinder into the waste. This cylinder was 
extracted and in turn used as the test cell for the closed-loop tracer test. This test was designed to examine the effect of scale on transport parameters.

Tests 8-13: Degrading and bio-suppressed Mechanically and Biologically Treated (MBT) waste was tested in parallel in two identical $0.48 \mathrm{~m}$ diameter laboratory columns. Two tests in each column were performed at $50 \mathrm{kPa}$ and subsequently one test was performed at $150 \mathrm{kPa}$ applied stress in each column. This test allowed comparison of a further waste type, but also allowed examination of the effect of degradation state.

\subsection{SIMULATION}

The solute transport model used to simulate these data, is described in detail in Woodman et al. (2013b), and is summarised here. The major hydraulic units (the reservoir, top and bottom gravel layers and the waste itself) are modelled using transfer functions (Jury \& Roth, 1990). The reservoir and gravel layers are simulated as perfectly mixed volumes. Tracer transport through the waste is simulated using a closed-loop dual porosity model, with the assumption of slab-shaped immobile blocks (Barker, 1985). This form of lumped model has been previously demonstrated to be appropriate for simulating aged and degrading waste (Woodman et al., 2005; Woodman et al., 2013b), despite expectation that the real geometry is complex. Conceivably, sub-parallel alignment of compressed plastic layers provides an approximately average block-like structure to the waste in the test-cells. There have been several studies which have found that diffusion to and from less mobile parts of the waste is an important transport mechanism (Bendz and Singh, 1999; Döberl et al., 2003; Rosqvist and Destouni, 2000; Woodman, 2007). These studies are supported by a broad evidence base as to the existence (albeit not the precise nature) of preferential flow (Bengtsson et al., 1994; Blakey, 1982; Ehrig, 1983; Fellner et al., 2009; Stegmann and Ehrig, 1989; Straub and Lynch, 1982).

Within the dual porosity concept there are many different levels of complexity which can be modelled. The model adopted here is kept as simple as possible. The volumetric water content $(\theta)$ is assumed to divide into two distinct overlapping continua represented by volumetric water contents in the mobile region $\left(\theta_{m}\right)$ and in the immobile region $\left(\theta_{i m}\right)$, which here is assumed to be slab-shaped. Mass transfer within the immobile region is assumed to be dominated by diffusion. Solute movement in and out of the immobile zone into the mobile zone is therefore governed by Fick's second law. A further key parameter is the characteristic block diffusion time, $t_{c b}=a^{2} / D_{a}$, where $a$ is the block dimension (the ratio of block volume to area) and $D_{a}$ is the apparent diffusion coefficient. This timescale therefore effectively characterises the (lumped average) dimension of immobile blocks. The size of immobile blocks relates to the spacing of preferred pathways. More widely spaced pathways will imply large blocks. Compression might both change the key block dimension directly by shortening, but also indirectly by diverting flow pathways. Fellner \& Brunner (2010) hypothesised that flow becomes increasingly preferential towards the base of the landfill, which would tend to increase the size of the immobile zone with depth.

The fixed parameters of the model are: volumetric water content $(\theta)$, length of waste $(L)$, cross-sectional area of column $(A)$, flow rate $(Q)$, volume of reservoir, sampling volumes, initial ('background') concentration of tracer in the recirculating liquid $\left(C_{b}\right)$, and volume of water contained in upper and lower confining gravel. The parameters which are varied to find a best-fit are, the mobile porosity $\left(\theta_{m}\right)$ and characteristic immobile zone diffusion time $\left(t_{c b}\right)$. The objective function used is the minimum sum of the square errors (SSE) between the 
data and the simulation. Levenburg-Marquardt optimisation was achieved using the UCODE programme (Poeter et al., 2005).

\section{RESULTS}

\subsection{EFFECT OF COMPRESSION ON HYDRAULICS}

Because of the need to correct for wall friction and self-weight, we hereafter relate our findings to the calculated average stress in the sample, rather than the applied stress. The calculation of average stress uses the relationship derived in Appendix 1 of Powrie and Beaven (1999), with an internal angle of friction of $40^{\circ}$, an angle of friction between the waste and column wall of $30^{\circ}$ and a unit weight of $10 \mathrm{kN} / \mathrm{m}^{3}$.

The water contents are plotted in Figure $2 \mathrm{a}$ and are shown in comparison to values reported in the literature. Crudely, the water content curves for the different wastes form a family of curves which are offset vertically. Some of the curves decrease most steeply up to around $200 \mathrm{kPa}$ average stress, and thereafter flatten and become insensitive to further compression (e.g. the processed waste described by Beaven, 2000). This trend is not universal and some, including the tests described in this paper, do not have a steep drop in water contents up to $200 \mathrm{kPa}$. The water content of the sub-sampled waste used in Test 7 was anomalously high for a highly compressed waste.

There are a number of different explanations for the variation in water content between samples. Firstly, different water contents are likely to arise where there are significant differences in pore structure, for instance through variations in waste composition, particle size distribution and packing method. A further important factor is the presence of gas within the sample, either through incomplete saturation during liquid addition or through displacement by biogenic gas. The symbols for the tests in which it is known that gas was being produced and was accumulating are coloured grey in Figure 2. Water contents in these can be seen to be reduced in comparison to those where gas has not accumulated.

The drainable porosity $\left(\theta_{d}\right)$ is shown in Figure $2 \mathrm{~b}$. This is defined as the volumetric fraction of free-draining water which arises from an initially saturated column of waste. This is not a fundamental parameter, since depending on the depth of the capillary fringe it potentially depends upon the dimensions of the column. Nonetheless, the test data conforms closely to the trends repeated in the literature. There is a relatively steep reduction in drainable porosity up to $100 \mathrm{kPa}$ average stress and thereafter less steep reductions, levelling off at around 2\%. Test 7 had an anomalously high drainable porosity. Consistent with the saturated water content, the biggest reductions in drainable porosity occurred for compression up to $200 \mathrm{kPa}$, thereafter the drainable porosity is relatively insensitive to compression.

The hydraulic conductivities for the tests for different average compressive stress are compared to literature in Figure 2c. Once more, Test 7 is observed to be anomalous, with a relatively high hydraulic conductivity for the stress level. The removal of the $600 \mathrm{kPa}$ applied load prior to coring, or the coring procedure itself, may have loosened the waste such that Test 7 behaved hydraulically like a waste which had experienced less than $100 \mathrm{kPa}$ average stress. The remaining tests reveal a consistent trend of declining hydraulic conductivity with average stress. For MSW2 which is sequentially compressed from test 3 to test 6 (by an average stress increase of $409 \mathrm{kPa}$ ), the hydraulic conductivity of the sample reduced by three orders of magnitude. 
The presence of gas is observed to reduce the hydraulic conductivity (Hudson et al. 2001) in addition to the effect of compression. Table 1 and Figure $2 \mathrm{c}$, show reductions in hydraulic conductivity due to the presence of gas (by an average of $47 \%$ throughout all the tests in MSW2). Shown on a semi-log scale, hydraulic conductivity continues to decline over the range of stresses plotted, unlike the water contents which stabilise. The on-going reductions in hydraulic conductivity observed for higher stresses are therefore achieved without reductions in volumetric water content, inferring a reduction in pore size but not relative volumetric fraction of pore space. Whilst the details of the size distribution of the connected pores are not known, these bulk observations nonetheless reveal that there are systematic changes in hydraulics (and waste density) that can be related to the applied or effective stress, and hence landfill depth. These systematic hydraulic changes due to compression have been shown to have important implications for how water flows through landfills. Powrie \& Beaven (1999) examined the differences to both predicted vertical and horizontal flows in landfills under (effective) stress-dependent flow. Given these observations, this paper aims to examine whether under increasing compression there are concomitantly significant changes in the localised pattern of flow and hence the nature of contaminant movement through wastes. Figure 2. (a) saturated volumetric water content, (b) drainable volumetric water content, starting from saturation and (c) hydraulic conductivity at saturation

\subsection{TRACER TESTS \\ BREAKTHROUGH CURVES}

The tracer concentrations measured at the outlet and reservoir are shown in Figure 3 together with the best model-fits which will be examined in Section 6. In all the tests a similar pattern was observed. For the reservoir, where the tracer was first injected the concentration was initially high, thereafter descending towards an equilibrium value. For the outlet the concentration rises at early-time due to breakthrough of the tracer which has come through the waste fed from the reservoir. At later time the concentration falls at a decreasing rate and where both BTCs were measured, they converged. It is noteworthy that test 7 did not exhibit tracer behaviour which was out of character compared to the remaining tests, despite giving hydraulically anomalous results.

Figure 3. Breakthrough curves with individual model fits for reservoir and outlet bromide data. Black circles denote samples taken from the reservoir and open circles denote samples taken from the outlet. Best-fit simulations are straight lines. Tests were closed-loop, except for test 0 where bromide was flushed by tap-water in an in-line test ( $\mathrm{LiCl}$ was also added to the flushing water- discussed in the main text) [note there was no reliable bromide data for tests 1,2 and 8 ]

\section{TRACER MASS BALANCE}

In tests 1-7, following the addition of the tracers, the reservoir concentrations were within $5 \%$ of the expected perfectly mixed concentrations. The exception was for lithium in test 2 where the expected concentration was $8 \%$ lower than measured. Since no single explanation for this could be isolated, the data from this test were neglected from the remaining analysis. The remaining data suggests that the reservoirs were well-mixed and that there were no significant and rapid reactions between the tracers and the leachate. In the tests on the MBT waste (tests 8-13) the concentrations were not measured in the reservoirs due to the configuration of the apparatus. 
The final (end of test) measured concentration in the system for a conservative (i.e. noninteracting) tracer would be equal to the concentration expected if the tracer had uniformly equilibrated with all the water contained within the closed-loop cell (adjusted for any sampling and liquid replacement). Thus, examination of the final concentration provides a simple method to compare the tracers and appraise whether they are conservative (in effect, a mass-balance is made). If the last sample is taken whilst the solute is still equilibrating, then the measured concentration would be expected to exceed the expected equilibrated concentration.

Figure 4. Measured against calculated (expected) tracer concentrations, (a) bromide, (b) lithium (c) deuterium, (d) lithium and bromide tracers compared on normalised axes (linear regression lines are shown for both tracers for degrading and non-degrading samples). Note the regressions overly, excepting lithium in degrading waste. Tracers are detailed in Table 1. Error bars are $+/-5 \%$, based on the greatest cumulative error associated with preservation, dilution and analysis of the samples.

Figure 4 compares measured and expected concentrations at the end of each test, relative to the line of equal expected and measured concentrations in the event of equilibrated conservative tracer addition.

For bromide, it can be seen in Figure 4a that the measured bromide is greater than or equal to the expected concentration in all of the tests with the exception of test 9 where it was $3 \%$ lower. In five of the tests the difference was more than $5 \%$ (tests 3, 4, 6, 10 and 11). This result is probably due to the test ending before full equilibration occurred.

For lithium, Figure $4 \mathrm{~b}$ shows that five of the final measured lithium concentrations are $5 \%$ or more below the expected concentration, indicating that in these cases less of the lithium is in solution in the cells than would be expected if it was fully conserved. Further inspection reveals that these were tests where there was active degradation. The exception is Test 4 , which is degrading but lies above the line. Test 4 was conducted in the winter, having lower temperature than the other degrading cells $\left(6^{\circ} \mathrm{C}\right.$ averaged over the test) and gas production was $30 \%$ of that recorded during the preceding test. The other tests under conditions where there was not significant active degradation (aged and bio-suppressed waste) fall on or above the line. This pattern apparently applies to different wastes in different apparati, as well as being observable for a fixed waste type and column design (e.g. MBT).

The deuterium fractions are compared in Figure 4c. A significant upward anomaly affected the MBT BTCs, and test 3 MSW2, whereas for the other BTCs the expected concentration is within $5 \%$ of the measured concentration. This may be due to fractionation during degradation and additionally be due to fractionation due to evaporation of leachate from the reservoir.

Figure $4 \mathrm{~d}$ gives the relative performance of the lithium and bromide tracers on the same graph, where the concentrations have been normalised to the maximum observed concentration of each tracer for all the tests. Regressions are shown for both tracers for degrading samples and non-degrading samples (note that test 4 is considered as nondegrading). Bromide and lithium tracers were added as a single salt to each test, so relative differences between the tracers for a given test cannot be attributed to discrepancies in the input mass. Differences between the tracers cannot be attributed to any bias in analysis 
instrument since firstly the ICPMS was calibrated against standards, and secondly because for all tracers it was observed that the reservoir concentrations balanced, to within 5\%. The bromide concentrations lie above the line of equal measured and expected concentrations, whereas six of the lithium concentrations are below the line. The linear regressions for bromide and for non-degrading lithium are close to being collinear, lying above this line, whereas the degrading lithium samples are below the line. These expected lithium concentrations are therefore both low in an absolute sense (relative to the line of measured and expected concentrations) and are even lower in a relative sense (compared to the bromide regression line).

Underestimation of the water content would lead to an over-estimation of the expected concentrations. An increase in the estimated water content of test would shift the corresponding data point for all the tracers to the left on each of the sub-plots of Figure 3. Therefore, the relative reduction in lithium compared to bromide and deuterium would be preserved independently of estimated water content.

The lithium mass-balance from a preceding conventional in-line tracer experiment in MSW2 (which we denote 'test 0') corroborates the relative 'loss' of lithium from the dissolved phase. In this test, the estimated lithium mass loss for the whole tracer BTC was $50 \%$ (Woodman et al., 2013a). Some of this was due to the test stopping before full equilibration. A second estimate of the loss is therefore made by fitting the BTC with a mass-adjustment factor. This provided an estimate of $28 \%$ lithium loss. Since bromide was flushed as an indigenous contaminant, a comparative mass-balance could not be made. Further corroborating evidence is given in Woodman \& Beaven (2011) who demonstrated that the lithium tracer results of Rosqvist and Bendz (1999) could also be consistent with a mass-loss of lithium in a degraded MSW.

These observations together suggest that lithium may be bound within the degrading waste cells. There are a number of possible mechanisms for this including sorption to charged surfaces on the waste, sorption to bio-films growing on the waste, sorption to colloidal matter which becomes trapped, or possibly precipitation through reaction with the leachate and/or waste. Until such possible mechanisms are properly quantified and understood in this context, caution should be expressed for future experiments using lithium as a tracer (especially in-line or field experiments where it is difficult to attribute a cause for tracer loss). Further work is needed in order to fully understand this mechanism and to explain why it was not detected in batch sorption experiments (Stegemann et al., 2006; Öman and Rosqvist, 1999).

Given the non-conservative behaviour of lithium and deuterium, bromide alone is selected here for modelling to allow a comparison which is uncomplicated by the possibility of tracer reaction or by variation of tracer type between the tests.

A mass-adjustment factor was implemented by Woodman et al. (2013b; 2013c) for analysing the non-conservative tracer BTCs. This assumed that any mass loss or gain could be simulated by an instantaneous change in the input concentration, such that the concentration at the input to the waste $C_{i}$ can be described by $C_{i}=C_{T} f$. The 'massadjustment' factor $f$ is in the range $0<f<1$ for a tracer which is 'lost' and mass-gain is simulated by $f>1$.

For the MBT waste (tests 8-13) there were no measurements of the reservoir concentration, making it impossible to verify the estimated initial concentration. Therefore for those tests a mass-adjustment factor was applied to the estimated initial 
concentration, whereas for all the other tests the measured reservoir initial concentration was used and the tracer thereafter considered to be conservative.

\section{SIMULATION OF BROMIDE BREAKTHROUGH}

\section{Table 3: Parameters for dual-porosity model (95\% confidence intervals given in brackets). $R$ ' is reservoir and ' $O$ ' is Outlet.}

Table 3 provides details of the fitting for the bromide data. The goodness-of-fit is reported as $\mathrm{R}^{2}$, rather than SSE, since there are different numbers of data in each test.

For all best-fits, $\theta_{m}$ was considerably below the measured volumetric water content. Indeed for most simulations $\theta_{m}$ was driven down to the lower limit which was set for calibration (0.01) below which is not likely to be physically-realistic. This apparently indicates a highly preferential flow system. This is consistent with the mobile porosities reported by Fellner et al. (2009) and Rosqvist \& Destouni (2000). The block diffusion times $\left(t_{c b} \mathrm{~s}\right)$ are plotted against the compressive stress in Figure 5.

Figure 5. Immobile block diffusion time, $t_{c b}$, against average compressive stress for bromide tracer. Error bars give the $95 \%$ confidence intervals on each estimation. ' $\mathrm{R}$ ' is sampled from reservoir and ' $\mathrm{O}$ ' is sampled from Outlet

Changes in block-diffusion times $\left(t_{c b}\right)$ are not nearly as significant as changes in hydraulic conductivity with compression, which span orders of magnitude (Figure 2c). For each waste type, there is only a slight decline in $t_{c b}$ with applied stress, plotted on log-axes. Given the considerable noise this may not reflect a real effect, yet it should be noted that a drop in $t_{c b}$ is consistent between samples and is comparable to the more modest declines observed for moisture content (Figure 2a). For the tests which have individually-fitted outlet ('O') and reservoir (' $\mathrm{R}$ ') data, there are differences between the optimum $t_{c b} \mathrm{~s}$, which exceed the individual 95\% confidence intervals. This suggests that the true parameter uncertainty exceeds that which is derived from fitting a single BTC.

The established block diffusion times for the MSW2 and MBT samples can be compared in Figure 5. These samples differed in two key respects, namely pre-treatment and test column size. The MSW2 tests were all performed in a $2 \mathrm{~m}$ diameter column, with the exception of Test 7, whereas the MBT tests were performed in a $0.48 \mathrm{~m}$ diameter column. Test 7 was performed in a $0.31 \mathrm{~m}$ diameter column and provided the lowest estimated $t_{c b}$ for MSW (1.4 days). With the exception of Test 9, all the smaller column results (i.e. the MBT plus Test 7) gave lower diffusion times than the results for the remaining MSW2 samples tested in the large column. This suggests a possible scaling effect, of increasingly large estimated block-diffusion times with measurement scale. Such scaling effects have been observed in waste (Rees-White et al., 2013) and in other porous media (Haggerty, 1999; Liu et al., 2004). One possible explanation is that given the heterogeneous nature of the true block geometry, for larger samples there is an increased probability of encountering large blocks which acts to increase the effective (lumped) block size that is observed.

These data do not fully disentangle whether waste type has a further significant influence, because the columns used to test the two waste types differed in scale. Test 7 is the only instance where scale is varied in the same waste. It was earlier noted that the hydraulic results for Test 7 behaved as if the sample had been unloaded to a lower stress (perhaps associated with the sampling). The results here demonstrate that if anything lower stress is 
likely to result in larger block-diffusion times, therefore the Test 7 result is most probably attributable to scale. It is possible that the anomaly is Test 7's hydraulics was associated with disturbance which rendered the column unreliable. However there is no evidence to support that possibility; the hydraulics were not outside the range seen in the other samples, the bromide tracer balanced adequately for this test and no other anomalies were noted. To validate this possible relationship a wider range in scales needs to be investigated, ultimately to the field scale which is of primary practical relevance.

For test 9 (MBT waste), $t_{c b}$ was estimated to be 53.8 days, considerably above the other MBT tests, which did not exceed 4.1 days. This relatively high value may correspond to more preferential flow at the start of the experiment before disturbance due to gas generation and compression encouraged a more even flow distribution (Woodman et al., 2013b).

The lack of strong systematic change between the tests might give further clues as to the nature of the dual-porosity flow system in waste. A conceptual model which may explain this behaviour is a system of flow making localised pathways downward between sub-parallel layers of low-permeability, thereby defining slab-like less-mobile zones between layers (Figure 6). In this geometry, diffusion into slabs would be predominantly in a horizontal direction and the block diffusion time dominated by the horizontal extent of the blocks (and the spacing between vertical pathways). Compression of the waste would not necessarily disturb the alignment of the low-permeability barriers nor change the horizontal length scale (thus timescale of diffusion) of the blocks, but simply compress them.

Figure 6. Conceptual sketch for how block diffusion time might be dominated by a horizontal length scale which is not strongly affected by compression.

\section{CONCLUSIONS}

Saturated volumetric water content, drainable water content and hydraulic conductivity of thirteen column tests were demonstrated to vary with average applied stress in a similar manner to that previously reported in the literature. For stress in excess of $200 \mathrm{kPa}$ the water content was insensitive to compression. In contrast (and again consistent with past observation) hydraulic conductivity remains sensitive to stress over the entire range examined (up to $560 \mathrm{kPa}$ ). Until now there has been little data to explain changes in transport properties exhibited with changes in stress and therefore how they change with depth of burial in a landfill. This paper therefore aimed to address this lack of knowledge.

Proper interpretation of tracer transport requires knowledge of either the absence of reaction of the tracer, or a thorough quantification of the reaction process. The conservatism of deuterium, lithium and bromide were therefore evaluated by comparison to expected equilibrated concentrations and to the other tracers.

Dissolved lithium was observed to undergo a (non-conservative) reduction in abundance in degrading and recently degraded waste. Conversely, dissolved lithium was observed to be conservative in highly aged wastes and wastes which degradation reactions have been biosuppressed. The removal of dissolved lithium may be due to bio-sorption but further investigation is needed. 
Deuterium was observed to undergo a non-conservative increase in abundance in degrading waste. This is thought to be due to fractionation associated with degradational reactions and possibly due to evaporation additionally.

Bromide, on the other hand, was observed to be conservative and was therefore used in this paper as the basis for simulation of conservative solute transport in all the tests based on a dual-porosity approach.

Based on simulation of the closed-loop bromide BTCs it was found that although hydraulic conductivity varies strongly with effective stress, the characteristic diffusion time is not changed equally substantially. A level of noise prevents a clear delineation of the relationship, but the relationship of timescale to applied stress is consistent with the subtler reductions in water content observed. This suggests that the characteristic length scales of diffusion in the waste are not significantly affected by compression. A viable conceptual model of the immobile block geometry is of 'slabs' constrained between sub-parallel layers of plastic, with the key length scale being horizontal.

For simulation of vertical flow and transport in waste, account needs to be taken of systematic changes to hydraulic conductivity and volumetric water content with compression (and therefore with depth). However, for vertical transport there is so far no evidence of systematic change for the range in applied stresses tested here $(87-600 \mathrm{kPa})$. If verified, this will potentially considerably simplify vertical transport modelling which is needed for interpreting field tracer tests and most importantly for simulating landfill flushing.

Finally, tentatively, the results show that the timescale of diffusion increased with experimental scale. This relationship requires verification at larger scales.

\section{TABLES}


Table 1. Summary of column conditions

\begin{tabular}{|c|c|c|c|c|c|c|c|c|c|c|c|c|}
\hline Test & Waste & $\begin{array}{l}\text { Degradation } \\
\text { state }\end{array}$ & $\begin{array}{l}\text { Stress } \\
\text { Applied } \\
\text { stress, } \\
\text { Averag } \\
\text { e Stress } \\
(\mathrm{kPa})\end{array}$ & $\begin{array}{l}\text { Vol. water } \\
\text { content } \theta \\
\text { (saturated, with } \\
\text { gas build up) }\end{array}$ & $\begin{array}{c}\mathrm{K} \\
\text { (saturated, with gas } \\
\text { build up) } \\
\mathrm{m} / \mathrm{s}\end{array}$ & $\begin{array}{l}\text { Flux } \\
\text { rate, } \mathrm{q} \\
(\mathrm{m} / \mathrm{d})\end{array}$ & $\begin{array}{l}\text { Dia. } \\
(\mathrm{mm})\end{array}$ & $\begin{array}{l}\text { Length } \\
(\mathrm{mm})\end{array}$ & $\begin{array}{l}\text { Liquid volume } \\
\text { (L) upper gravel, } \\
\text { lower gravel, } \\
\text { reservoir, waste } \\
\text { (with gas build } \\
\text { up) }\end{array}$ & $\begin{array}{l}\text { Sample: } \\
\text { Reservoir } \\
\quad(\mathrm{R}) \\
\text { or Outlet } \\
\quad(\mathrm{O})\end{array}$ & $\begin{array}{l}\text { Duration of } \\
\text { test (days) }\end{array}$ & $\begin{array}{l}\text { Publications } \\
\text { relating to test. }\end{array}$ \\
\hline 0 & MSW2 & $\begin{array}{l}\text { Degrading } \\
\text { (D) }\end{array}$ & 87,69 & $0.68,0.54$ & $1.1 \mathrm{E}-5,1.1 \mathrm{E}-6$ & 0.03 & 2000 & 1644 & 99,117, N/A, 2762 & $\begin{array}{c}\mathrm{O} \text { (inline } \\
\text { test, not } \\
\text { circulating) }\end{array}$ & 32 & $\begin{array}{l}\text { Woodman } e t \\
\text { al.(2013a) }\end{array}$ \\
\hline 1 & MSW1 & Aged (A) & 50,40 & $0.52,0.31$ & $1.2 \mathrm{E}-5, \mathrm{~N} / \mathrm{A}$ & 0.20 & 480 & 314 & $8,35,43,17.9$ & $\mathrm{R}, \mathrm{O}$ & 42 & $\begin{array}{l}\text { Ivanova et al. } \\
\quad(2008)\end{array}$ \\
\hline 2 & MSW1 & Aged (A) & $\begin{array}{l}150 \\
122 \\
\end{array}$ & $0.48,0.31$ & N/A & 0.03 & 480 & 247 & $8.5,35,50,13.8$ & $\mathrm{R}, \mathrm{O}$ & 42 & $\begin{array}{l}\text { Beaven } \text { et al. } \\
\quad \text { (2007) }\end{array}$ \\
\hline 3 & MSW2 & $\begin{array}{l}\text { Degrading } \\
\text { (D) }\end{array}$ & 87,69 & N/A, 0.52 & $2.3 \mathrm{E}-5,1.9 \mathrm{E}-6$ & 0.06 & 2000 & 1644 & $99,117,403,2687$ & $\mathrm{R}, \mathrm{O}$ & 43 & $\begin{array}{l}\text { Woodman et al. } \\
\text { (2009) }\end{array}$ \\
\hline 4 & MSW2 & $\begin{array}{l}\text { Degrading } \\
\text { (D) }\end{array}$ & $\begin{array}{l}150 \\
118\end{array}$ & $0.59,0.53$ & $2.2 \mathrm{E}-6,1.7 \mathrm{E}-6$ & 0.07 & 2000 & 1445 & $99,117,413,2420$ & $\mathrm{R}, \mathrm{O}$ & 42 & \\
\hline 5 & MSW2 & $\begin{array}{l}\text { Degrading } \\
\text { (D) }\end{array}$ & $\begin{array}{l}300, \\
236\end{array}$ & $0.55,0.52$ & $8.9 \mathrm{E}-7,7.5 \mathrm{E}-7$ & 0.09 & 2000 & 1293 & $99,117,330,2127$ & $\mathrm{R}, \mathrm{O}$ & 27 & \\
\hline 6 & MSW2 & $\begin{array}{l}\text { Degrading } \\
\text { (D) }\end{array}$ & $\begin{array}{l}600 \\
478\end{array}$ & $0.54,0.49$ & $4.0 \mathrm{E}-8,26 \mathrm{E}-8$ & 0.01 & 2000 & 1156 & $99,117,267,1771$ & $\mathrm{R}, \mathrm{O}$ & 45 & \\
\hline 7 & MSW2 & $\begin{array}{l}\text { Degrading } \\
\text { (D) }\end{array}$ & $\begin{array}{l}600 \\
560\end{array}$ & 0.61, N/A & $1.1 \mathrm{E}-4,2.2 \mathrm{E}-5$ & 0.37 & 314 & 354 & $1.4,2.0,6.4, \mathrm{~N} / \mathrm{A}$ & $\mathrm{R}, \mathrm{O}$ & 34 & \\
\hline 8 & MBT & $\begin{array}{l}\text { Degrading } \\
\text { (D) }\end{array}$ & 50,38 & N/A, 0.41 & $5.9 \mathrm{E}-6, \mathrm{~N} / \mathrm{A}$ & 0.19 & 480 & 350 & $4,9,42,26$ & $\mathrm{R}$ & 30 & $\begin{array}{l}\text { Siddiqui } \text { et al. } \\
\quad \text { (2012) }\end{array}$ \\
\hline 9 & MBT & $\begin{array}{l}\text { Bio- } \\
\text { suppressed } \\
\text { (BS) }\end{array}$ & 50,38 & N/A, 0.50 & 6.6E-6, N/A & 0.19 & 480 & 358 & $4,9,34,33$ & $\mathrm{R}$ & 30 & $\begin{array}{l}\text { Woodman et al. } \\
\text { (2013b) }\end{array}$ \\
\hline 10 & MBT & Aged (A) & 50,39 & N/A, 0.41 & N/A, N/A & 0.19 & 480 & 343 & $4,9,42,25$ & $\mathrm{R}$ & 27 & \\
\hline 11 & MBT & $\begin{array}{l}\text { Bio- } \\
\text { suppressed } \\
\text { (BS) }\end{array}$ & 50,38 & N/A, 0.51 & N/A, N/A & 0.19 & 480 & 354 & $4,9,35,32$ & $\mathrm{R}$ & 27 & \\
\hline \multirow[t]{2}{*}{12} & MBT & Aged (A) & 150 & N/A, 0.41 & 6.7E-7, N/A & 0.19 & 480 & 314 & $4,9,44,24$ & $\mathrm{R}$ & 26 & \\
\hline & & & & & & & & & & & & 14 \\
\hline
\end{tabular}




\begin{tabular}{|c|c|c|c|c|c|c|c|c|c|c|c|c|}
\hline Test & Waste & $\begin{array}{l}\text { Degradation } \\
\text { state }\end{array}$ & $\begin{array}{l}\text { Stress } \\
\text { Applied } \\
\text { stress, } \\
\text { Averag } \\
\text { e Stress } \\
(\mathrm{kPa}) \\
\end{array}$ & $\begin{array}{l}\text { Vol. water } \\
\text { content } \theta \\
\text { (saturated, with } \\
\text { gas build up) }\end{array}$ & $\begin{array}{c}\mathrm{K} \\
\text { (saturated, with gas } \\
\text { build up) } \\
\mathrm{m} / \mathrm{s}\end{array}$ & $\begin{array}{l}\text { Flux } \\
\text { rate, } \mathrm{q} \\
(\mathrm{m} / \mathrm{d})\end{array}$ & $\begin{array}{l}\text { Dia. } \\
(\mathrm{mm})\end{array}$ & $\begin{array}{l}\text { Length } \\
(\mathrm{mm})\end{array}$ & $\begin{array}{l}\text { Liquid volume } \\
\text { (L) upper gravel, } \\
\text { lower gravel, } \\
\text { reservoir, waste } \\
\text { (with gas build } \\
\text { up) }\end{array}$ & $\begin{array}{l}\text { Sample: } \\
\text { Reservoir } \\
\quad(\mathrm{R}) \\
\text { or Outlet } \\
\quad(\mathrm{O})\end{array}$ & $\begin{array}{c}\text { Duration of } \\
\text { test (days) }\end{array}$ & $\begin{array}{c}\text { Publications } \\
\text { relating to test. }\end{array}$ \\
\hline 13 & MBT & $\begin{array}{l}\text { Bio- } \\
\text { suppressed } \\
(\mathrm{BS})\end{array}$ & $\begin{array}{l}116 \\
150 \\
115\end{array}$ & N/A, 0.48 & 8.0E-7, N/A & 0.19 & 480 & 325 & $4,9,39,29$ & $\mathrm{R}$ & 26 & \\
\hline
\end{tabular}


Table 2 Tracer details for each test

\begin{tabular}{|c|c|c|c|c|}
\hline Waste & Tracer & Tests & $\begin{array}{l}\text { Background } \\
\text { concentration }\end{array}$ & $\begin{array}{l}\text { Measured reservoir } \\
\text { concentration } \\
\text { following tracer } \\
\text { addition }\end{array}$ \\
\hline MSW2 & $\begin{array}{l}\text { Anhydrous lithium chloride (99\%) (Fisher } \\
\text { Scientific Ltd). } \\
\text { 99\% concentration of } \mathrm{D}_{2} \mathrm{O} \text { (CAF number 7789- } \\
\text { 20-0, Cambridge Isotope Laboratories Inc, } \\
\text { product code DLM-4-99-1000) }\end{array}$ & 0 & $\begin{array}{l}0.6 \mathrm{mg} \mathrm{Li} / \mathrm{L} \\
-22 \% \circ \mathrm{D}_{2} \mathrm{O} \\
561.1 \mathrm{mg} \mathrm{Br} / \mathrm{L}\end{array}$ & $\begin{array}{l}37.1 \mathrm{mg} \mathrm{Li} / \mathrm{L} \text { (injected } \\
\text { concentration) } \\
1598 \% \mathrm{D}_{2} \mathrm{O}\end{array}$ \\
\hline \multirow[t]{2}{*}{ MSW1 } & \multirow{2}{*}{$\begin{array}{l}\text { Anhydrous lithium bromide }(99 \%+) \text { (Fisher } \\
\text { Scientific Ltd) } \\
\mathrm{D}_{2} \mathrm{O} \text { at a purity of } 99 \%(\mathrm{CK} \text { Gas Products Ltd) }\end{array}$} & 1 & $0.8 \mathrm{mg} \mathrm{Li} / \mathrm{L}$ & $31.3 \mathrm{mg} \mathrm{Li} / \mathrm{L}$ \\
\hline & & 2 & $0.1 \mathrm{mg} \mathrm{Li} / \mathrm{L}$ & $27.6 \mathrm{mg} \mathrm{Li} / \mathrm{L}$ \\
\hline \multirow[t]{5}{*}{ MSW2 } & \multirow{5}{*}{$\begin{array}{l}\text { Lithium bromide }(>99 \%) \text { (Sigma Aldrich) } \\
99 \% \text { concentration of } \mathrm{D}_{2} \mathrm{O} \\
\text { (CAF number } 7789-20-0 \text {, Cambridge Isotope } \\
\text { Laboratories Inc, product code DLM-4-99-1000) }\end{array}$} & 3 & $\begin{array}{l}0.2 \mathrm{mg} \mathrm{Li} / \mathrm{L} \\
188.8 \mathrm{mg} \mathrm{Br} / \mathrm{L} \\
14 \% o \mathrm{D}_{2} \mathrm{O}\end{array}$ & $\begin{array}{l}50.3 \mathrm{mg} \mathrm{Li} / \mathrm{L} \\
785.4 \mathrm{mg} \mathrm{Br} / \mathrm{L} \\
1547 \% \circ \mathrm{D}_{2} \mathrm{O}\end{array}$ \\
\hline & & 4 & $\begin{array}{l}5.4 \mathrm{mg} \mathrm{Li} / \mathrm{L} \\
243 \mathrm{mg} \mathrm{Br} / \mathrm{L}\end{array}$ & $\begin{array}{l}45.4 \mathrm{mg} \mathrm{Li} / \mathrm{L} \\
719 \mathrm{mg} \mathrm{Br} / \mathrm{L}\end{array}$ \\
\hline & & 5 & $\begin{array}{l}8.0 \mathrm{mg} \mathrm{Li} / \mathrm{L} \\
323 \mathrm{mg} \mathrm{Br} / \mathrm{L}\end{array}$ & $\begin{array}{l}29.8 \mathrm{mg} \mathrm{Li} / \mathrm{L} \\
597.0 \mathrm{mg} \mathrm{Br} / \mathrm{L}\end{array}$ \\
\hline & & 6 & $\begin{array}{l}9.8 \mathrm{mg} \mathrm{Li} / \mathrm{L} \\
361.2 \mathrm{mg} \mathrm{Br} / \mathrm{L}\end{array}$ & $\begin{array}{l}39.6 \mathrm{mg} \mathrm{Li} / \mathrm{L} \\
708.9 \mathrm{mg} \mathrm{Br} / \mathrm{L}\end{array}$ \\
\hline & & 7 & $\begin{array}{l}3.8 \mathrm{mg} \mathrm{Li} / \mathrm{L} \\
447.3 \mathrm{mg} \mathrm{Br} / \mathrm{L}\end{array}$ & $\begin{array}{l}28.1 \mathrm{mg} \mathrm{Li} / \mathrm{L} \\
725.2 \mathrm{mg} \mathrm{Br} / \mathrm{L}\end{array}$ \\
\hline \multirow[t]{6}{*}{ MBT } & \multirow{6}{*}{$\begin{array}{l}>99 \% \text { lithium bromide (Sigma Aldrich) } \\
99 \% \text { concentration of } \mathrm{D}_{2} \mathrm{O} \\
\text { (CAF number } 7789-20-0 \text {, Cambridge Isotope } \\
\text { Laboratories Inc, product code DLM-4-99-1000) }\end{array}$} & 8 & $-37.8 \% \circ \mathrm{D}_{2} \mathrm{O}$ & $591.3 \% \circ \mathrm{D}_{2} \mathrm{O}$ \\
\hline & & 9 & $\begin{array}{l}0.2 \mathrm{mg} \mathrm{Li} / \mathrm{L} \\
29.3 \mathrm{mg} \mathrm{Br} / \mathrm{L}\end{array}$ & $\begin{array}{l}24.9 \mathrm{mg} \mathrm{Li} / \mathrm{L} \\
373.2 \mathrm{mg} \mathrm{Br} / \mathrm{L}\end{array}$ \\
\hline & & 10 & $\begin{array}{l}0.0 \mathrm{mg} \mathrm{Li} / \mathrm{L} \\
68.5 \mathrm{mg} \mathrm{Br} / \mathrm{L} \\
315 \% \circ \mathrm{D}_{2} \mathrm{O}\end{array}$ & $\begin{array}{l}\text { 30.0mg Li/L } \\
416.2 \mathrm{mg} \mathrm{Br} / \mathrm{L} \\
952.1 \% \circ \mathrm{D}_{2} \mathrm{O}\end{array}$ \\
\hline & & 11 & $\begin{array}{l}11.2 \mathrm{mg} \mathrm{Li} / \mathrm{L} \\
133.4 \mathrm{mg} \mathrm{Br} / \mathrm{L}\end{array}$ & $\begin{array}{l}41.1 \mathrm{mg} \mathrm{Li} / \mathrm{L} \\
480.2 \mathrm{mg} \mathrm{Br} / \mathrm{L}\end{array}$ \\
\hline & & 12 & $\begin{array}{l}11.5 \mathrm{mg} \mathrm{Li} / \mathrm{L} \\
241.1 \mathrm{mg} \mathrm{Br} / \mathrm{L} \\
720.5 \% \circ \mathrm{D}_{2} \mathrm{O} \\
\end{array}$ & $\begin{array}{l}41.4 \mathrm{mg} \mathrm{Li} / \mathrm{L} \\
586.9 \mathrm{mg} \mathrm{Br} / \mathrm{L} \\
1357.7 \% \circ \mathrm{D}_{2} \mathrm{O} \\
\end{array}$ \\
\hline & & 13 & $\begin{array}{l}23.3 \mathrm{mg} \mathrm{Li} / \mathrm{L} \\
301.1 \mathrm{mg} \mathrm{Br} / \mathrm{L}\end{array}$ & $\begin{array}{l}53.2 \mathrm{mg} \mathrm{Li} / \mathrm{L} \\
647.1 \mathrm{mg} \mathrm{Br} / \mathrm{L}\end{array}$ \\
\hline
\end{tabular}

Notes: All lithium and bromide samples were preserved with nitric acid $(0.01 \mathrm{ml}$ acid $/ \mathrm{mL}$ sample). The samples for $\mathrm{D}_{2} \mathrm{O}$ analysis were stored untreated in McCartney bottles to prevent evaporation. Lithium analysis: Tests 0, 3-7 by ICPMS (Thermo Scientific X-series); Tests 1-2 and 8-13 by Atomic Absorption Spectrophotometer (SpectrAA200, Varian). Bromide analysis: Tests 3-7 by ICPMS; Tests 8-13 by ion selective electrode (Thermo Orion). $\mathrm{D}_{2} \mathrm{O}$ analysis by VG-Optima mass spectrometer. 
Table 3: Parameters for dual-porosity model (95\% confidence intervals given in brackets). $R^{\prime}$ ' is reservoir and ' $O$ ' is Outlet.

\begin{tabular}{|c|c|c|c|c|c|c|c|}
\hline & Test & $\begin{array}{l}\text { Condition } \\
\text { (degradation } \\
\text { state, applied } \\
\text { load) }\end{array}$ & $\begin{array}{l}\theta \\
\left(\mathrm{m}^{3} / \mathrm{m}^{3}\right) \\
\text { Fixed }\end{array}$ & $\begin{array}{l}t_{c b} \\
\text { (d) } \\
\text { Fitted }\end{array}$ & $\begin{array}{l}\theta_{m} \\
\left(\mathrm{~m}^{3} / \mathrm{m}^{3}\right) \\
\text { Fitted }\end{array}$ & $\begin{array}{l}f \\
(-) \\
\text { Fitted/fixed }\end{array}$ & $\begin{array}{l}R^{2} \\
(-) \\
\text { Calc }\end{array}$ \\
\hline$\sum_{\sum}^{\infty}$ & 0 & $\begin{array}{l}\text { Undegraded, } \\
87 \mathrm{kPa}\end{array}$ & 0.54 & $42.3(38.0-46.5)$ & 0.01 & Fixed $=1$ & 0.962 \\
\hline \multirow{2}{*}{$\sum_{\sum}^{-1}$} & 1 & $\mathrm{~N} / \mathrm{A}$ & N/A & N/A & $\mathrm{N} / \mathrm{A}$ & $\mathrm{N} / \mathrm{A}$ & $\mathrm{N} / \mathrm{A}$ \\
\hline & 2 & $\mathrm{~N} / \mathrm{A}$ & $\mathrm{N} / \mathrm{A}$ & N/A & $\mathrm{N} / \mathrm{A}$ & $\mathrm{N} / \mathrm{A}$ & $\mathrm{N} / \mathrm{A}$ \\
\hline \multirow{5}{*}{$\sum_{\sum}^{\infty}$} & 3 & $\begin{array}{l}\text { Undegraded, } \\
87 \mathrm{kPa}\end{array}$ & 0.52 & $\begin{array}{l}142.0(124.6-156.0) \mathrm{O} \\
247.6(175.6-351.3) \mathrm{T}\end{array}$ & $\begin{array}{l}0.01 \\
0.01\end{array}$ & Fixed $=1$ & $\begin{array}{l}0.794 \\
0.975\end{array}$ \\
\hline & 4 & $\begin{array}{l}\text { Undegraded, } \\
150 \mathrm{kPa}\end{array}$ & 0.53 & $\begin{array}{l}231.9(187.2-287.3) \mathrm{O} \\
142.5(110.1-184.4) \mathrm{T}\end{array}$ & $\begin{array}{l}0.01 \\
0.01\end{array}$ & Fixed $=1$ & $\begin{array}{l}0.773 \\
0.966 \\
\end{array}$ \\
\hline & 5 & $\begin{array}{l}\text { Undegraded, } \\
300 \mathrm{kPa}\end{array}$ & 0.52 & $\begin{array}{l}36.6(26.4-50.8) \mathrm{O} \\
41.0(23.4-71.8) \mathrm{T}\end{array}$ & $\begin{array}{l}0.01 \\
0.01\end{array}$ & Fixed $=1$ & $\begin{array}{l}0.583 \\
0.882\end{array}$ \\
\hline & 6 & $\begin{array}{l}\text { Undegraded, } \\
600 \mathrm{~Pa}\end{array}$ & 0.49 & $\begin{array}{l}197.5(155.0-251.7) \mathrm{O} \\
363.1(140.5-585.8) \mathrm{T} \\
\end{array}$ & $\begin{array}{l}0.01 \\
0.01 \\
\end{array}$ & Fixed $=1$ & $\begin{array}{l}0.792 \\
0.915 \\
\end{array}$ \\
\hline & 7 & $\begin{array}{l}\text { Undegraded, } \\
600 \mathrm{~Pa}\end{array}$ & 0.49 & $\begin{array}{l}1.4(1.0-2.0) \mathrm{O} \\
3.6(2.0-6.5) \mathrm{T} \\
\end{array}$ & $\begin{array}{l}0.01 \\
0.01 \\
\end{array}$ & Fixed $=1$ & $\begin{array}{l}0.723 \\
0.956 \\
\end{array}$ \\
\hline \multirow{6}{*}{$\stackrel{\leftarrow}{\Sigma}$} & 8 & $\begin{array}{l}\text { Undegraded, } \\
50 \mathrm{kPa}\end{array}$ & 0.41 & $\mathrm{~N} / \mathrm{A}$ & N/A & $\mathrm{N} / \mathrm{A}$ & $N / A$ \\
\hline & 9 & $\begin{array}{l}\text { Undegraded, } \\
50 \mathrm{kPa}\end{array}$ & 0.50 & $53.8(21.6-134.0)$ & $0.08(0.07-0.1)$ & $0.95(0.88-1.01)$ & 0.986 \\
\hline & 10 & Aged 50Kpa & 0.41 & $1.9(1.6-2.2)$ & 0.01 & $1.02(1.01-1.04)$ & 0.993 \\
\hline & 11 & $\begin{array}{l}\text { Undegraded, } \\
50 \mathrm{kPa}\end{array}$ & 0.51 & $4.1(2.7-6.3)$ & $0.16(0.13-0.19)$ & $1.29(1.26-1.32)$ & 0.988 \\
\hline & 12 & Aged 50Kpa & 0.41 & $1.8(1.5-2.2)$ & 0.01 & 1.05 (1.04-1.07) & 0.990 \\
\hline & 13 & $\begin{array}{l}\text { Undegraded, } \\
50 \mathrm{kPa}\end{array}$ & 0.48 & $1.1(0.9-1.4)$ & 0.01 & $1.11(1.09-1.13)$ & 0.984 \\
\hline
\end{tabular}




\section{FIGURES}

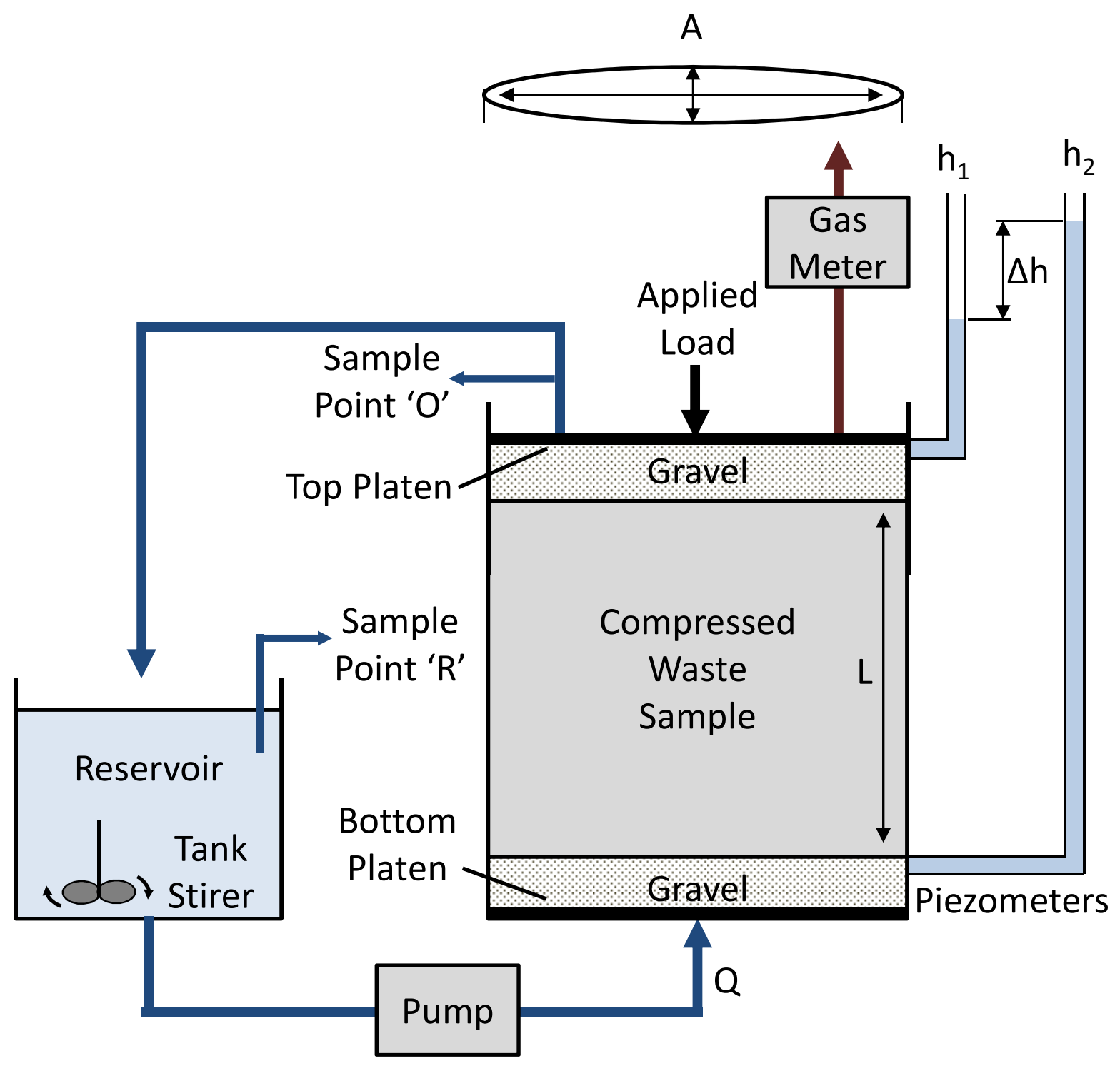

(a) Tests 3-7 


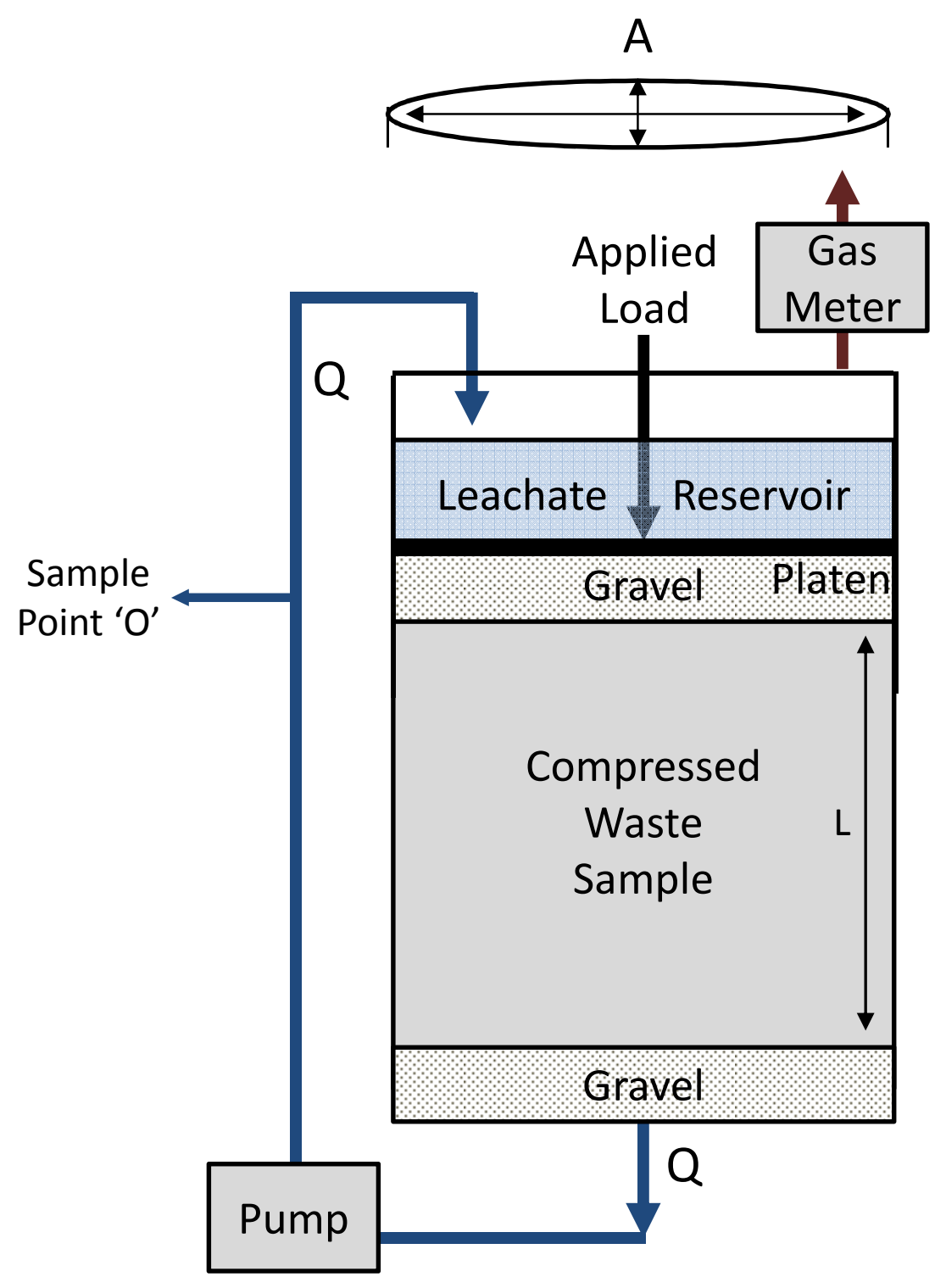

(b) Tests 1-2, 8-13

Figure 1. Schematics of major hydraulic elements in the closed-loop tracer tests. 

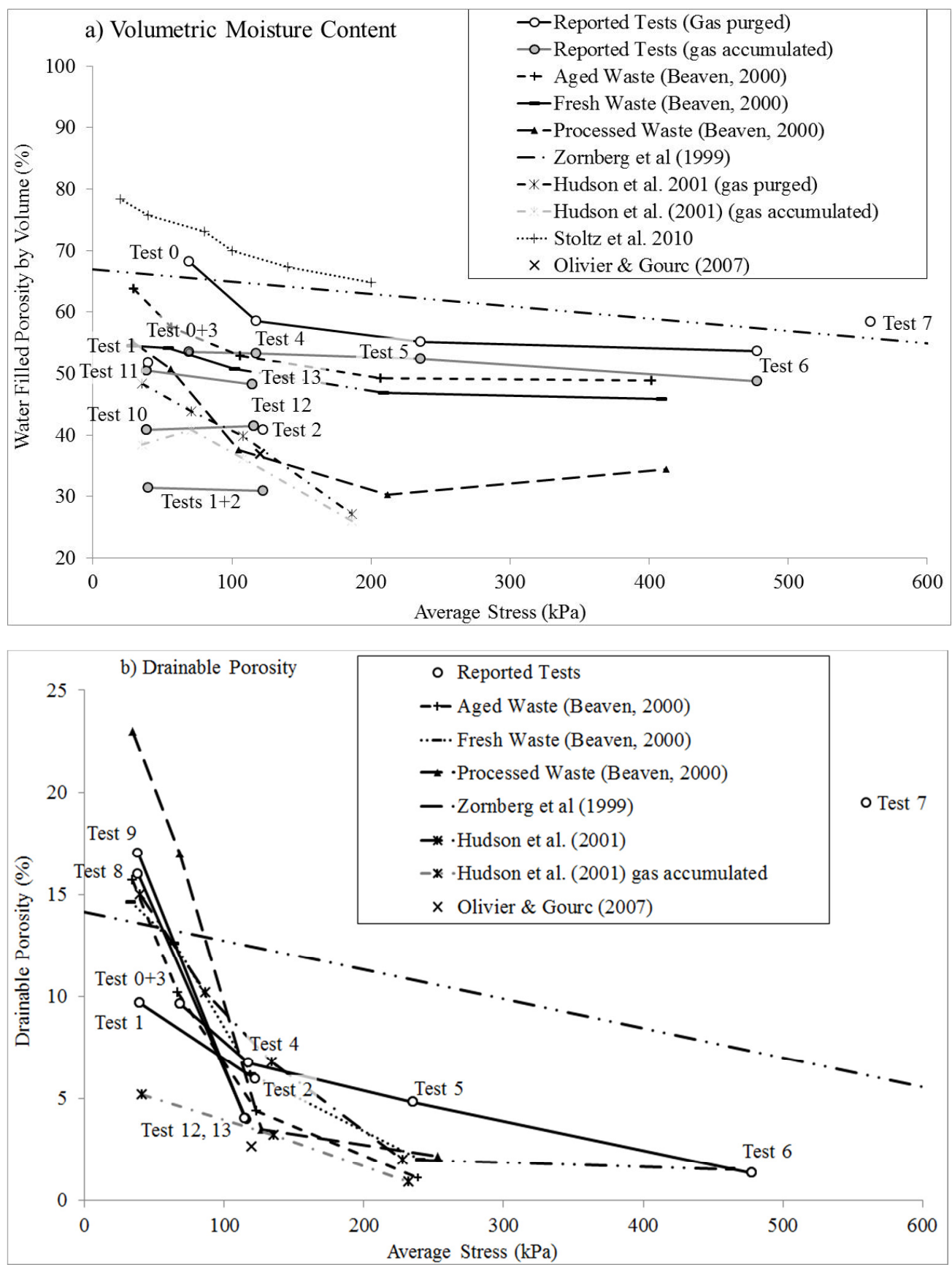


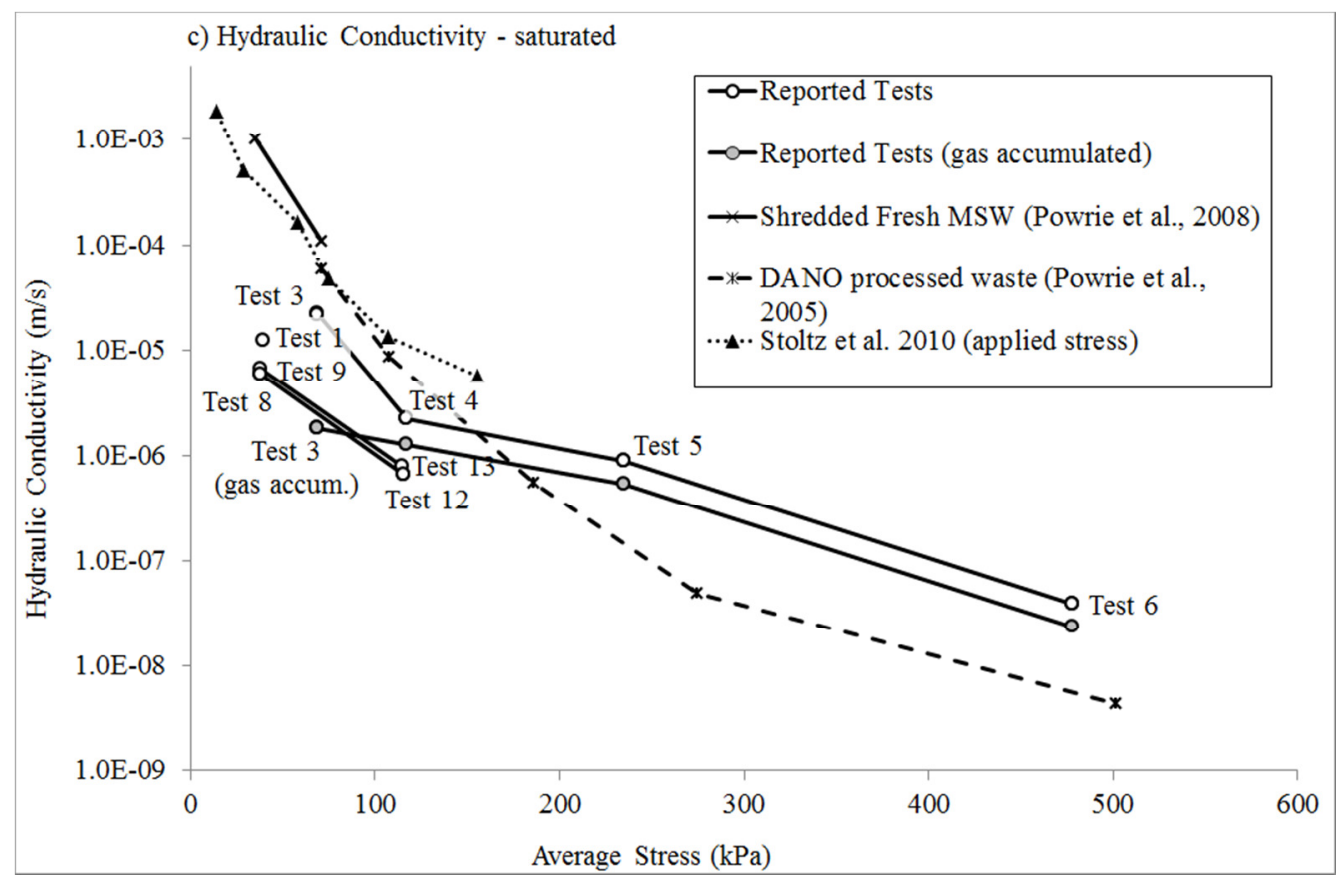

Figure 2. (a) Volumetric water content at start of test compared to literature values, (b) Drainable porosity compared to literature values, (c) Hydraulic conductivity. (Notes: Measurements are under saturated conditions unless it is indicated that gas has accumulated. Tests given by open circles and joined by solid lines where the same sample was sequentially compressed. Literature values are connected by non-solid lines. Samples where gas was accumulated are given in grey) 
Test 0

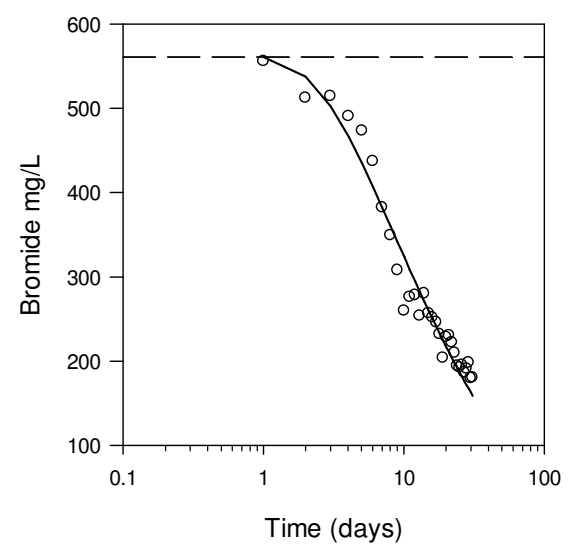

Test 4

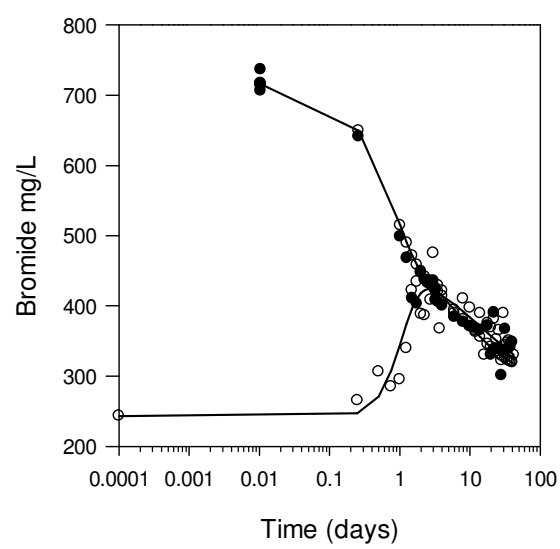

Test 6

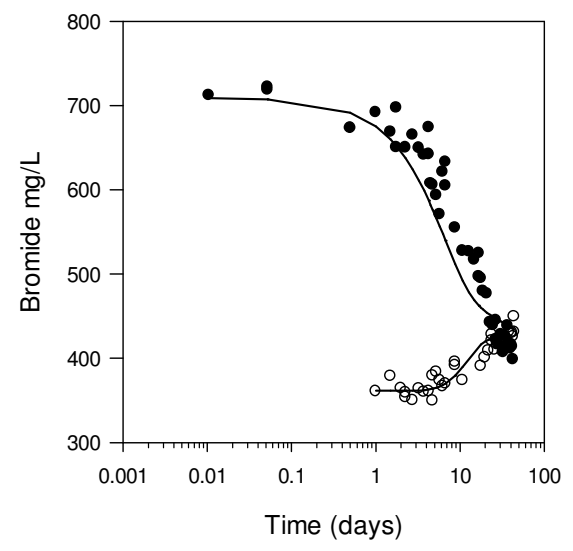

Test 3

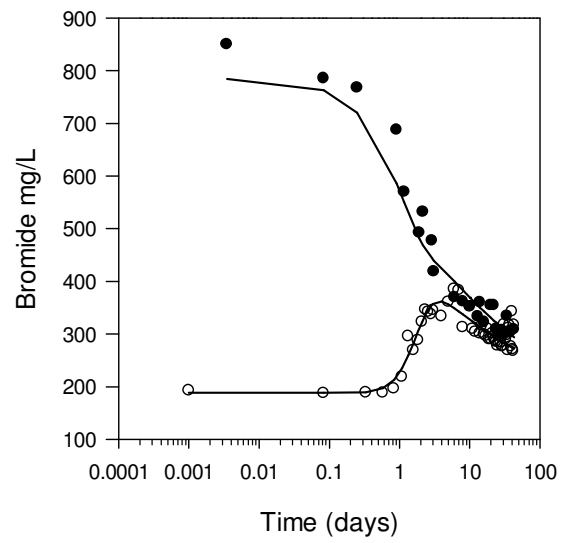

Test 5

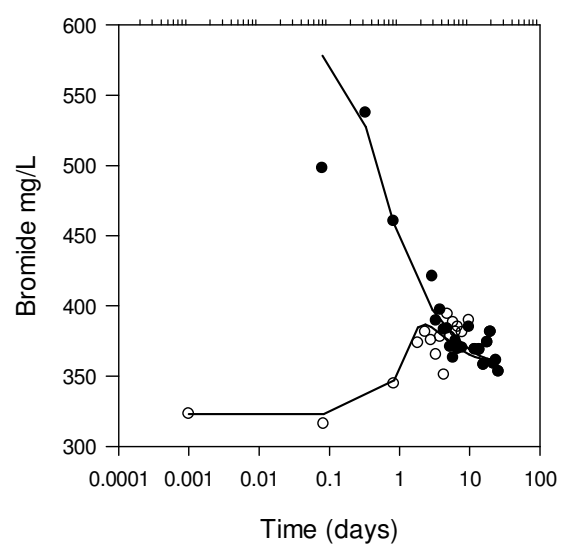

Test 7

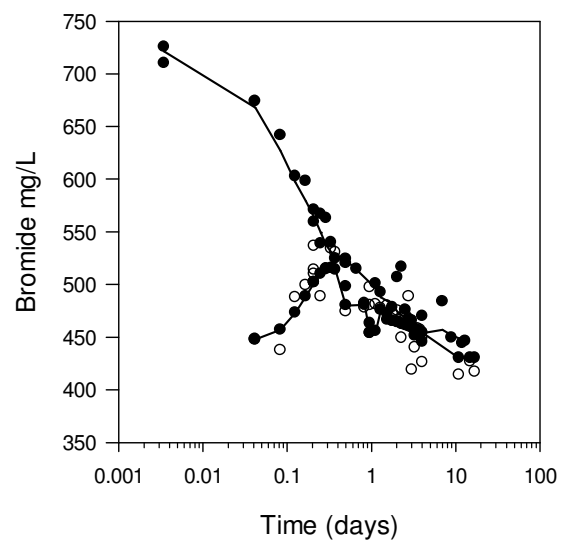


Test 9

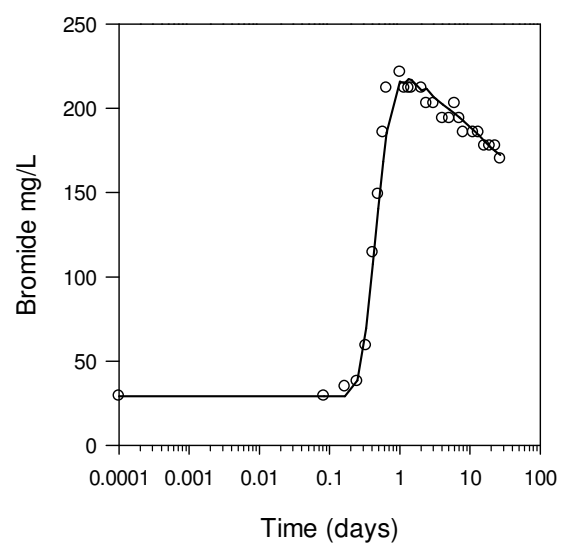

Test 11

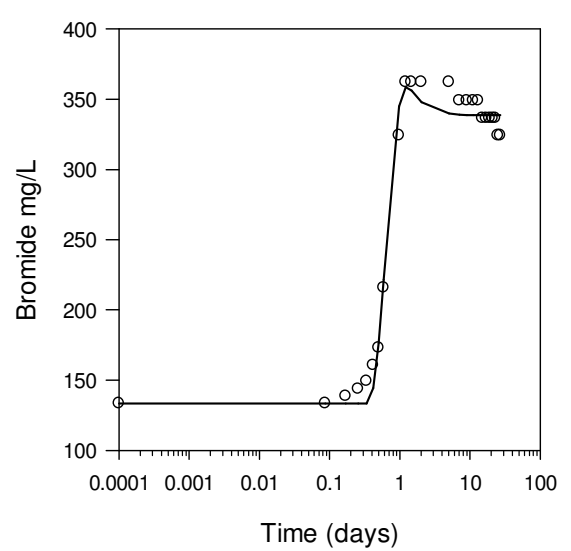

Test 13

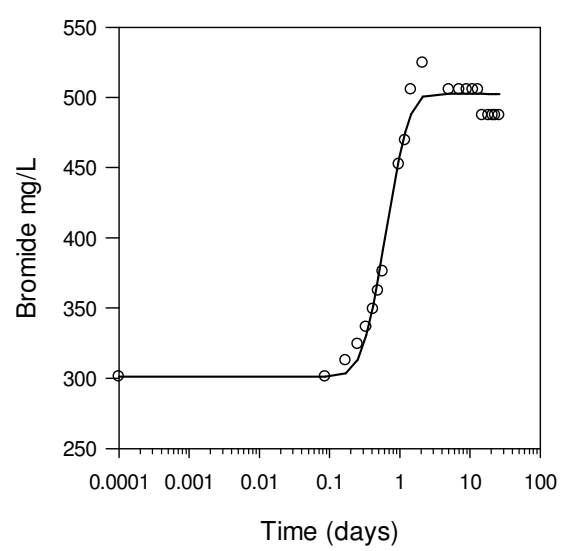

Test 10

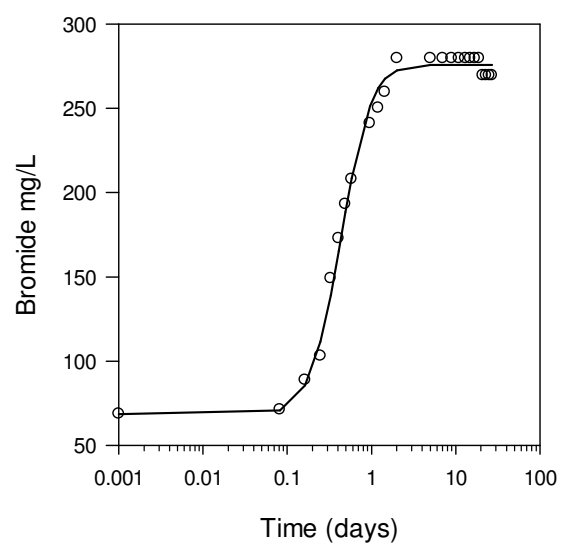

Test 12

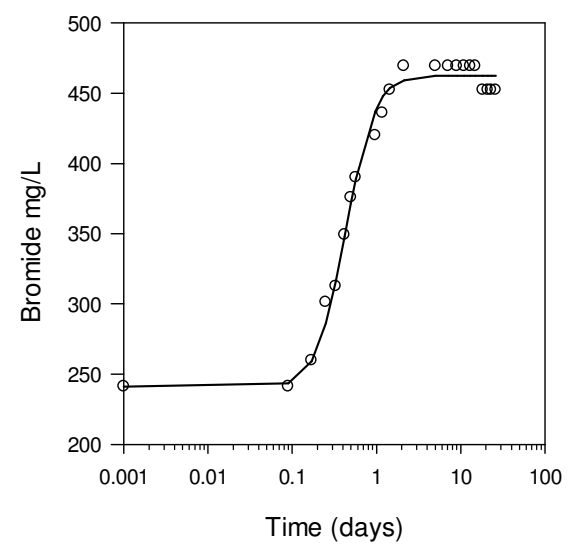

Figure 3. Breakthrough curves with individual model fits for reservoir and outlet bromide data. Black circles denote samples taken from the reservoir and open circles denote samples taken from the outlet. Best-fit simulations are straight lines. Tests were closed-loop, except for test 0 where bromide was flushed by tap-water in an in-line test ( $\mathrm{LiCl}$ was also added to the flushing water- discussed in the main text). Dashed line in test 0 denotes average background concentration prior to the test. [note there was no reliable bromide data for tests 1,2 and 8 ] 
(a) bromide balance

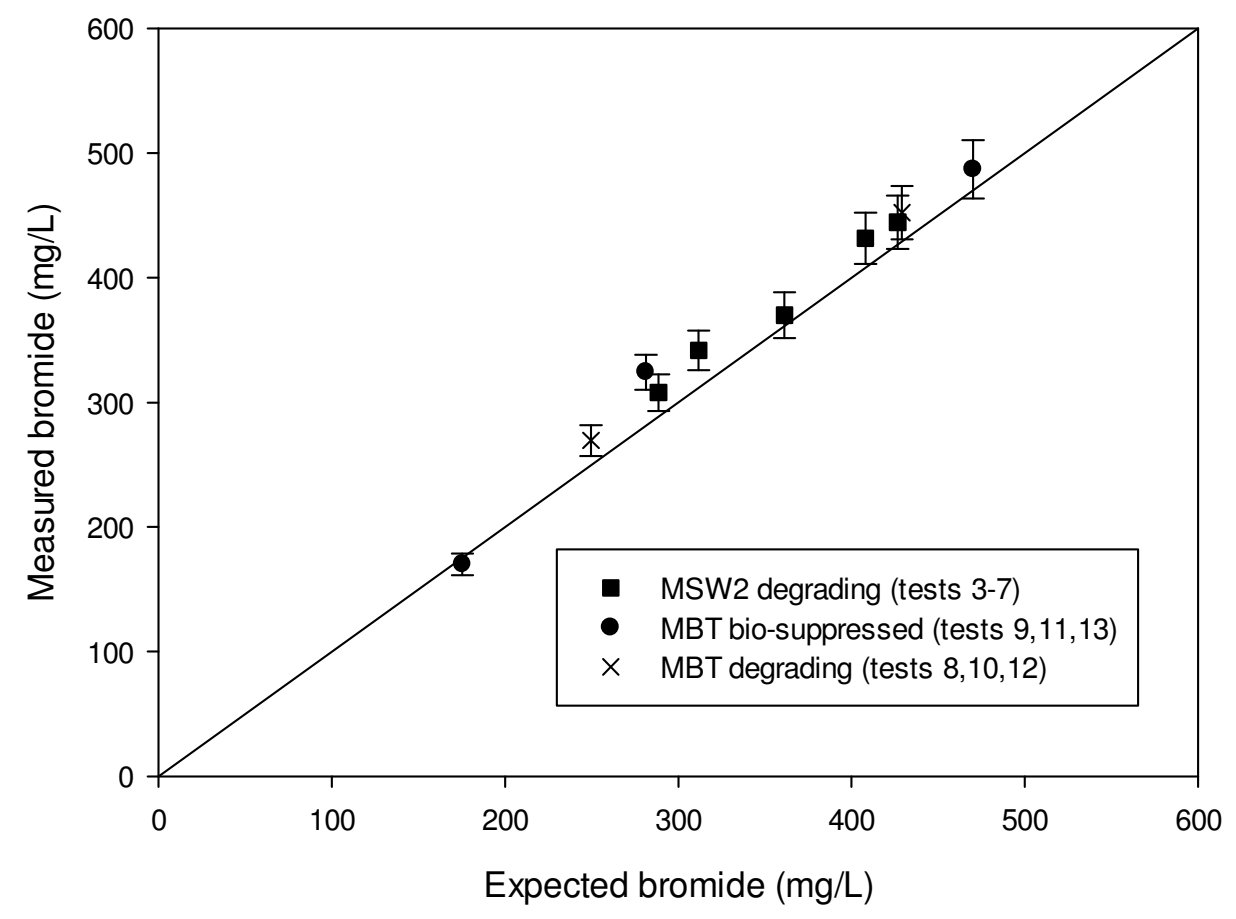

(b) lithium balance

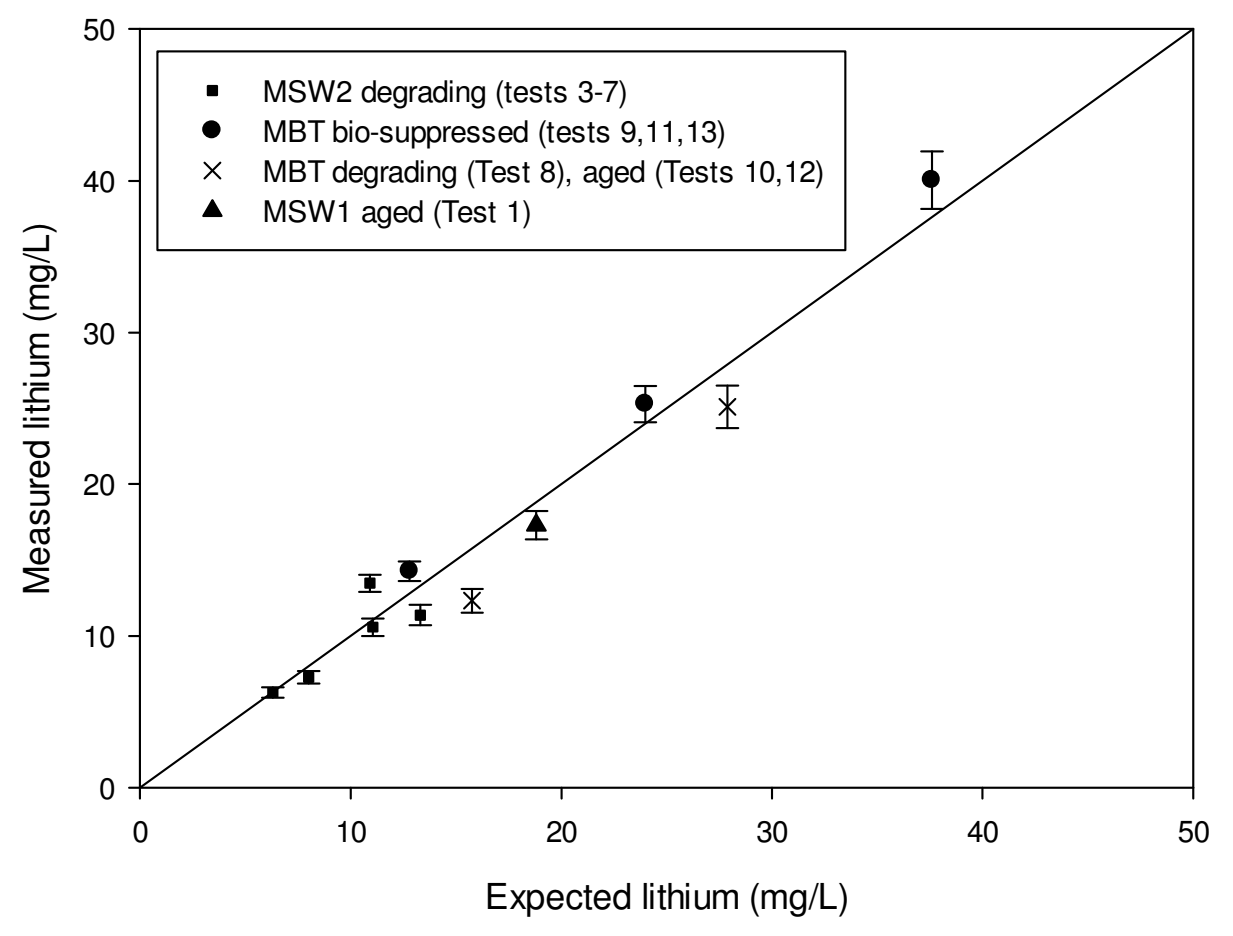


(c) deuterium balance

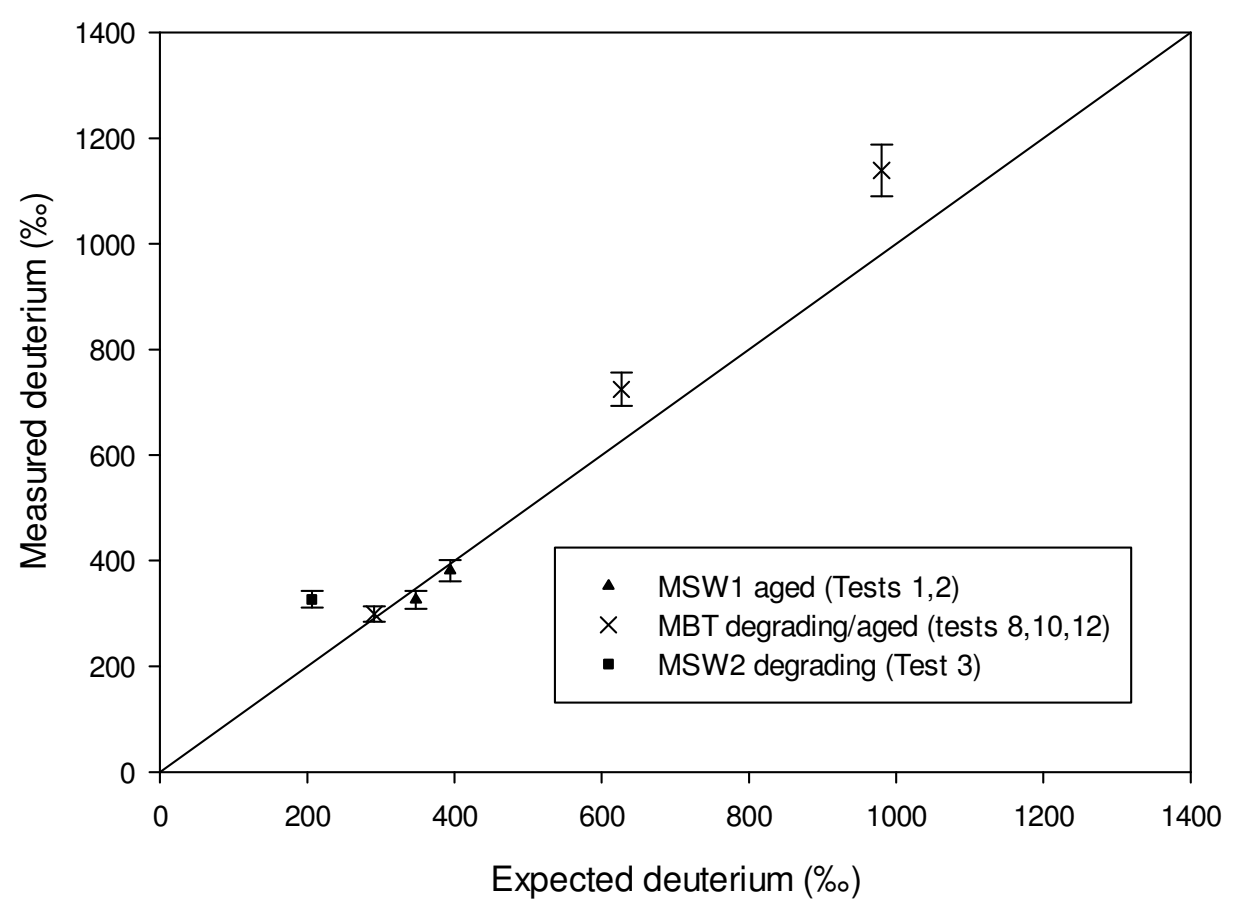




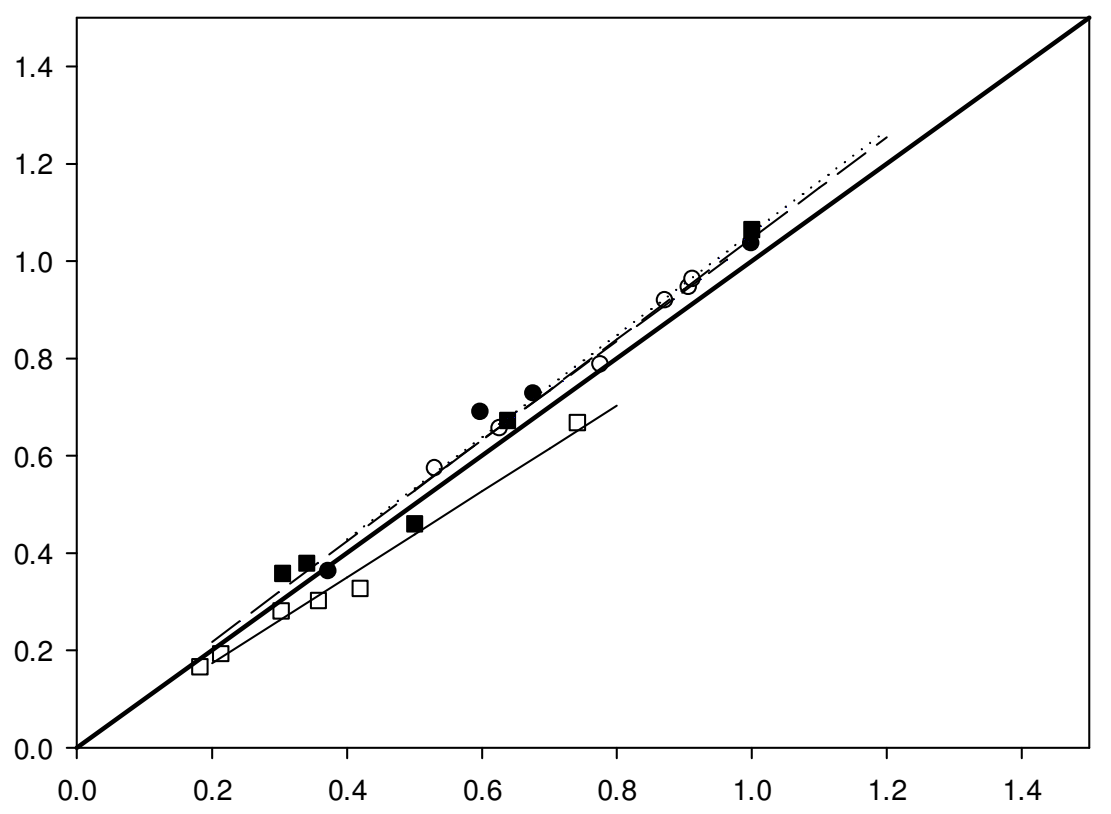

Expected concentration (normalised to max expected concentration)

\begin{tabular}{|c|c|}
\hline$\bullet$ & $\mathrm{Br}$ - non-degrading waste \\
\hline 0 & $\mathrm{Br}$ - degrading waste \\
\hline - & $\mathrm{Li}$ - non-degrading waste \\
\hline$\square$ & $\mathrm{Li}$ - degrading waste \\
\hline & Expected=measured \\
\hline & Regress $-\mathrm{Li}$ in degrading waste $\left(\mathrm{R}^{2}=0.985\right)$ \\
\hline$--ー-ー---$ & Regress - $\mathrm{Li}$ in non-degrading waste $\left(\mathrm{R}^{2}=0.982\right)$ \\
\hline-------- & Regress - $\mathrm{Br}$ in degrading waste $\left(\mathrm{R}^{2}=0.993\right)$ \\
\hline & Regress - $\mathrm{Br}$ in non-degrading waste $\left(\mathrm{R}^{2}=0.979\right)$ \\
\hline
\end{tabular}

Figure 4. Measured against calculated (expected) tracer concentrations, (a) bromide, (b) lithium (c) deuterium, (d) lithium and bromide tracers compared on normalised axes (linear regression lines are shown for both tracers for degrading and non-degrading samples). Note the regressions overly, excepting lithium in degrading waste. Tracers are detailed in Table 1. Error bars are $+/-5 \%$, based on the greatest cumulative error associated with preservation, dilution and analysis of the samples. 


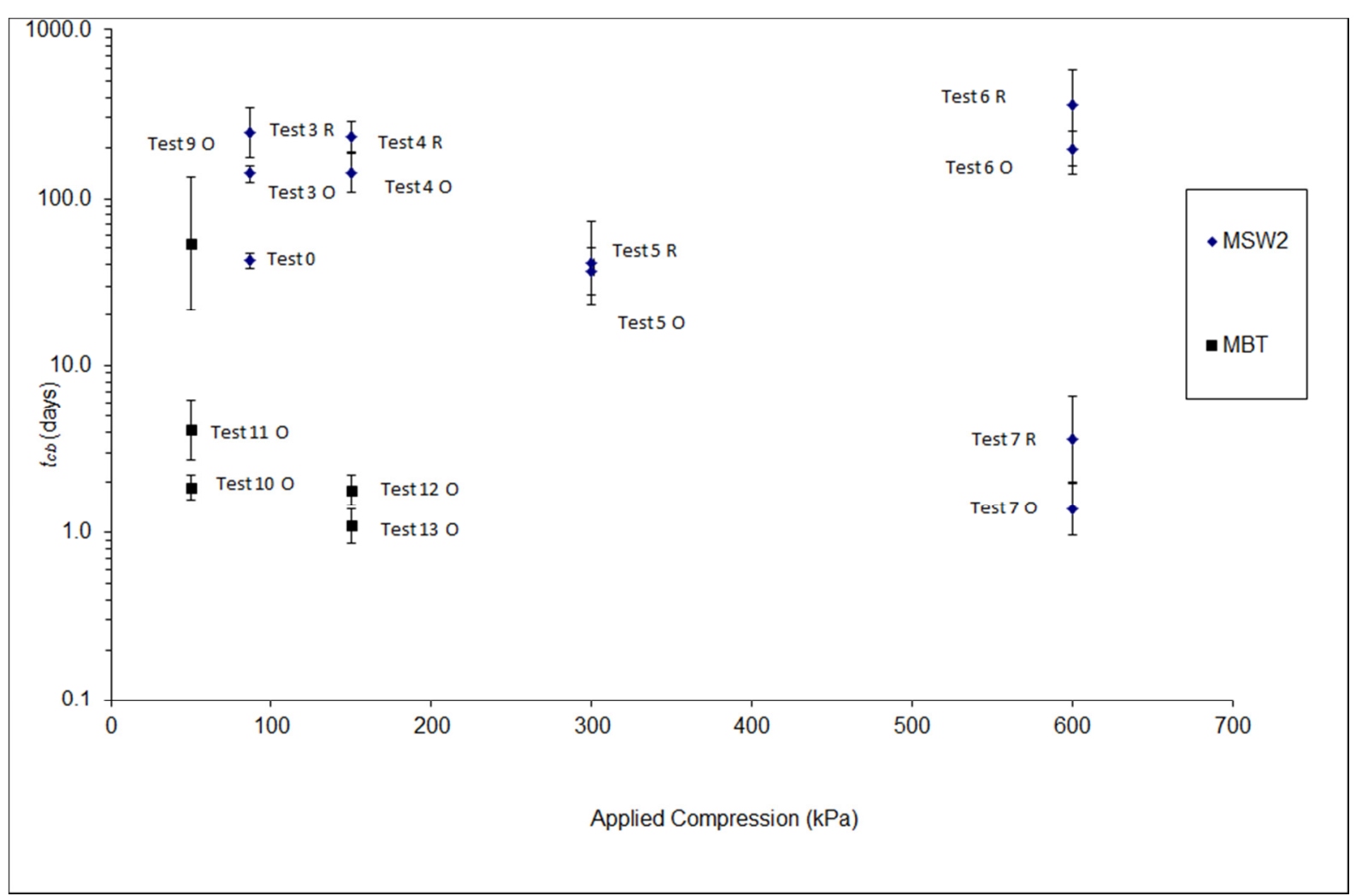

Figure 5. Immobile block diffusion time, $t_{c b}$, against average compressive stress for bromide in MSW2 and MBT. Error bars give the 95\% confidence intervals on each estimation. ' $\mathrm{R}$ ' is sampled from reservoir and ' $\mathrm{O}$ ' is sampled from Outlet 


\section{NOMENCLATURE}

a Immobile block characteristic dimension (ratio of block volume to area) (L)

$A \quad$ Cross sectional area of waste $\left(\mathrm{L}^{2}\right)$

$C_{b}$ Initial tracer concentration within the system ('background') $\left(\mathrm{ML}^{-3}\right)$

$D_{a}$ Apparent diffusion coefficient $\left(\mathrm{L}^{2} \mathrm{~T}^{-1}\right)$

$K$ Hydraulic conductivity $\left(\mathrm{LT}^{-1}\right)$

$L \quad$ Length of sample (L)

$Q \quad$ Flow rate $\left(\mathrm{L}^{3} \mathrm{~T}^{-1}\right)$

$t_{c b} \quad$ Characteristic time of diffusion in immobile zone (T)

$\theta \quad$ Volumetric water content (-)

$\theta_{m}$ Volumetric water content of mobile zone (-)

$\theta_{i m}$ Volumetric water content of immobile zone (-)

$\theta_{s} \quad$ Saturated volumetric water content (-)

$\theta_{d} \quad$ Drainable (volumetric) water content (-)

\section{ACKNOWLEDGEMENTS}

This work was supported by EPSRC grants: EP/E041965/1: "Science and strategies for the long-term management and remediation of landfills" and EP/E00654X/1 (2006), "Mechanics and settlement of post Landfill Directive residual wastes". Prof John Barker is thanked for his key inputs into experimental design and modelling. Hans van der Sloot and Laurent Oxarango are both thanked for providing their data.

\section{REFERENCES}

Baedeker, M. and W. Back (1979). "Hydrogeological processes and chemical reactions at a landfill " Groundwater 17(5): 429-437.

Barker, J. A. (1985). "Block-Geometry functions characterizing transport in densely fissured media." Journal of Hydrology 77: 263-279.

Beaven, R.P. (2000). “The hydrogeological and geotechnical properties of household waste in relation to sustainable landfilling”. PhD Thesis, University of London, London.

Beaven, R.P., Barker, J.A. and Hudson, A. (2003). "Description of a tracer test through waste and application of a double porosity model", Sardinia 2003: Proceedings of the Ninth International Waste Management and Landfill Symposium, Margherita di Pula, Cagliari, Sardinia, Italy.

Beaven, R.P., Ivanova, L.K. and Woodman, N.D. (2007). Multi-tracer closed loop tests on a well degraded waste under variable compression. In: R. Cossu, L.F. Diaz and R. Stegmann (Editors), Sardinia 
2007. Eleventh International Waste Management and Landfill Symposium, S. Margherita di Pula Cagliari, Sardinia, Italy.

Bendz, D. and V. P. Singh (1999). "Solute transport under steady and transient conditions in biodegraded municipal solid waste." Water Resources Research 35(8): 2333-2345.

Bengtsson, L., D. Bendz, W. Hogland, H. Rosqvist and M. Akesson (1994). "Water balance for landfills of different age." Journal of Hydrology 158: 203-217.

Blakey, N. (1982). "Infiltration and adsorption of water by domestic wastes in landfills, research carried out by WRC", paper presented at Harwell Landfill Leachate Symposium, UK, UK Atomic Energy Authority, Oxon, England.

Blakey, N.C., Blackmore, K. and Clarke, L. (1998). "Application of tracer studies for monitoring leachate recirculation in landfills”. CWM 171/98, Environment Agency, Report CWM 171/98.

Döberl, G., R. Huber, J. Fellner and P. H. Brunner (2003). "The heterogeneity of waste as a main factor influencing the future emission potential of MSW landfills - a case study on the Breitenau-Landfill in Austria”. Sardinia 2003, Ninth International Waste Management and Landfill Symposium, S. Margherita di Pula, Cagliari, Sardinia, Italy.

Ehrig, H. J. (1983). "Quantity and quality of sanitary landfill leachate." Waste Management and Research 1: 53-68.

Fellner, J., G. Doberl, G. Allgaier and P. H. Brunner (2009). "Comparing field investigations with laboratory models to predict landfill leachate emissions." Waste Management 29: 1844-1851.

Fellner, J. and P. Brunner, H. (2010). "Modeling of leachate generation from MSW landfills by a 2dimensional 2-domain approach." Waste Management 30: 2084-2095.

Flury, M. and Flühler, H. (1995). "Tracer characteristics of Brilliant Blue FCF”. Soil Sci. Soc. Am. J., 59: 22-27.

Hackley, K., C. Liu and D. Coleman (1996). "Environmental isotope characteristics of landfill leachates and gases." Goundwater 34(5): 827-836.

Haggerty, R. (1999). "Application of the multirate diffusion approach in tracer test studies at Äspö HRL”, Svensk Kärnbränslehantering AB (SKB).

Harris, M. R. R. (1979). “A study on the behaviour of refuse as a landfill material” PhD, Portsmouth Polytechnic.

Harris, R. C., Knox, K. \& Walker, A. N. (1994) “A strategy for the development of sustainable landfill design and operation". Proceedings of the Institute of Waste Management., Jan-94, 26-29.

Hudson, A.P., Beaven, R.P. and Powrie, W. (1999). "Measurement of the hydraulic conductivity of household waste in a large scale compression cell", Sardinia 99, Seventh International Waste Management and Landfill Symposium, S Margherita di Pula, Cagliari, Italy, pp. 461-468.

Hudson, A.P., Beaven, R.P. and Powrie, W. (2001). "Interaction of water and gas in saturated household waste in a large scale compression cell", Sardinia 2001, Eighth International Waste Management and Landfill Symposium, S Margherita di Pula, Cagliari, Italy. 
Hudson, A. P., R. P. Beaven, J. K. White and W. Powrie (2004). "Modelling the compression behaviour of landfilled domestic waste." Waste Management 24: 259-269.

Ivanova, L.K., Richards, D.J. and Smallman, D.J. (2008). "The long term settlement of landfill waste". Waste and Resource Management 161(WR3): 121-133.

Jury, W. A. and K. Roth (1990). "Transfer Functions and Solute Transport Through Soil: Theory and Applications"., Birkhaeuser Publ. Basel. 235 p.

Liu, H. H., G. S. Bodvarsson and G. Zhang (2004). "Scale Dependency of the Effective Matrix Diffusion Coefficient." Vadose Zone Journal 3: 312-315.

Maloszewski, P., Moser, H., Stichler, W. and Trimborn, P. (1995). "Isotope hydrology investigations in large refuse lysimeters". Journal of Hydrology, 167: 149-166.

Olivier, F. and Gourc, J.P. (2007). "Hydro-Mechanical behaviour of Municipal Solid Waste subject to leachate recirculation in a large-scale compression reactor cell". Waste Management, 27: 44-58.

Öman, C. and Rosqvist, H. (1999). "Transport fate of organic compounds with water through landfills". Water Research, 33(10): 2247-2254.

Poeter, E.P., Hill M.C., Banta, E.R., Mehl, S., Christensen and Steen, 2005. UCODE_2005 and six other computer codes for universal sensitivity analysis, calibration, and uncertainty evaluation. U.S. Geological Survey Techniques and Methods. 6-A11.

Powrie, W. and Beaven, R.P. (1999). "Hydraulic properties of household waste and implications for landfills”. Proc. Instn Civ. Engrs Geotech. Engng,, 137: 235-247.

Powrie, W., Beaven R.P. and Hudson A.P. (2005) "Factors affecting the hydraulic conductivity of waste", International Workshop "Hydro-physico-mechanics of landfills", Ed. Gourc J.P., Grenoble (2005). Page 40

Powrie W., Beaven R.P. and Hudson A.H. (2008) "The influence of landfill gas on the hydraulic conductivity of waste" In: Proceedings of Geocongress 2008 Annual Congress of the Geo-Institute of ASCE, Ed. ASCE, New Orleans, Louisiana, USA

Raco, B., E. Dotsika, R. Battaglini, E. Bulleri, M. Doveri and K. Papakostantinou (2013). "A Quick and Reliable Method to Detect and Quantify Contamination from MSW Landfills: a Case Study." Water air and soil pollution $\mathbf{2 2 4}(3)$.

Rees-White, T., N. D. Woodman and R. P. Beaven (2013). "Evaluating echo tests as a landfill contaminant transport characterisation tool". 5th International Workshop Hydro-Phyico-Mechanics of Landfill,. J. MacDougall. Napier University, Edinburgh.

Rosqvist, H. and Bendz, D. (1999). "An experimental evaluation of the solute transport volume in biodegraded municipal solid waste." Hydrology and Earth System Science, 3(3): 429-438.

Rosqvist, H. and G. Destouni (2000). "Solute transport through preferential pathways in municipal solid waste." Journal of Contaminant Hydrology 46: 39-60. 
Siddiqui, A.A., Richards, D.J. and Powrie, W. (2012). "Investigations into the landfill behaviour of pretreated wastes". Waste Management, 32( 7): 1420-1426.

Stegmann and Ehrig (1989). "Leachate production and quality: results of landfill processes and operation. Proceedings". Sardinia 89, Second International Landfill Symposium, S Margherita di Pula, Cagliari, Sardinia, Italy.

Stegemann, J.A., Lin, J. and Beaven, R.P. (2006). "Preliminary investigation of the sorption of common landfill tracers to MSW", Waste 2006, Stratford-Upon-Avon.

Stoltz, G., Gourc J-P, Oxarango, L. (2010). "Liquid and gas permeabilities of unsaturated municipal solid waste under compression". Journal of Contaminant Hydrology, 118: 27-42.

Straub, W. A. and D. R. Lynch (1982). "Models of landfill leaching: moisture flow and inorganic strength." Journal of Environmental Engineering, ASCE 108: 231-250.

Ward, R.S., Barker, J.A., Williams, A.T., Brewerton, L.J. and Gale, I.N. (1998). "Groundwater Tracer Tests: a review and guidelines for their use in British Aquifers". WD/98/19 Hydrogeology Series, BGS.

Woodman, N. D., J. A. Barker and R. P. Beaven (2005). "Identification of transport processes from a tracer test through waste". Sardinia 2005 Tenth International Waste Management and Landfill Symposium, S Margherita di Pula, Cagliari, Sardinia, Italy.

Woodman, N. D. (2007). "Modelling of transport in heterogeneous porous media with application to solute transport in landfills" $\mathrm{PhD}$, University College London.

Woodman, N.D., Rees-White, T., Beaven, R.P. and Hudson, A. (2009). "Refining experimental method for fluid flow experiments on MSW in a large scale uniaxial compression cell". Sardinia 2009. Twelfth International Waste Management and Landfill Symposium, S. Margherita di Pula, Cagliaria, Sardinia, Italy.

Woodman, N. D., A. M. Stringfellow, W. Powrie, H. A. B. Potter, A. Simoes, A. Marcosanti, F. Lazzarini and C. Pavani (2011). "Transport of Mecoprop through Mercia Mudstone and Oxford Clay at the Laboratory Scale." Quarterly Journal of Engineering Geology and Hydrogeology 44: 331-344.

Woodman, N. D. and R. P. Beaven (2011). "Assessment of simple preferential flow concepts for transport through municipal solid waste”. Sardinia 2011, Thirteenth International Waste Management and Landfill Symposium. R. Cossu, P. He, P. Kjeldsen et al. Margherita di Pula, Cagliari, Sardinia, Italy.

Woodman, N.D., Rees-White, T., Stringfellow, A., Beaven, R.P. and Hudson, A.P. (2013a). "Multiple tracer experiments for process identification in saturated municipal solid waste”. In: J. MacDougall (Editor), 5th International Workshop Hydro-Phyico-Mechanics of Landfill, Napier University, Edinburgh, pp. 35-42.

Woodman, N.D., Siddiqui, A.A., Powrie, W., Stringfellow A., Beaven, R.P., Richards, D.J. (2013b). "Quantifying the effect of settlement and gas on solute flow and transport through treated municipal solid waste". Journal of Contaminant Hydrology, 153: 106-121.

Woodman, N. D., T. Rees-White, A. Stringfellow, R. P. Beaven and A. P. Hudson (2013c). "Provisional analysis of the effect of compression on transport in degrading municipal solid waste". Sardinia 2013, Fourteenth International Waste Management and Landfill Symposium. Cossu. S. Margherita di Pula, Cagliari, Italy, CISA Publisher, Italy 
Zornberg, J.G., Jernigan, B.L., Sanglerat, T.R. and Cooley, B.H. (1999) "Retention of free liquids in landfills undergoing vertical expansion". Journal of Geotechnical and Geoenvironmental Engineering. 125: $583-594$. 